Elsevier Editorial System(tm) for Microchemical Journal Manuscript Draft

Manuscript Number: MICROC-D-15-00514

Title: Characterisation of Roman and Byzantine glasses from the surroundings of Thugga (Tunisia): raw materials and colors

Article Type: VSI: TECHNART 2015

Keywords: Late antique glass; Tunisia; elemental composition; XRF; XPS; FORS

Corresponding Author: PhD, Prof Paola Fermo, associate professor

Corresponding Author's Institution: Università degli Studi di Milano

First Author: Paola Fermo, associate professor

Order of Authors: Paola Fermo, associate professor; Martina Andreoli, PhD, researcher; Letizia Bonizzoni, PhD, researcher; Marzia Fantauzzi, PhD, researcher; Giulia Giubertoni; Nicola Ludwig, phD, researcher; Antonella Rossi, professor

Abstract: Roman and Byzantine glass shards collected during excavation campaigns around the ancient city of Thugga in northern Tunisia have been characterised by means of various analytical techniques. pXRF (portable X-Ray Fluorescence) and SEM-EDX (scanning electron microscopy coupled with energy dispersive X-ray analysis) were used to determine the glass matrix elemental composition and to identify the elements responsible for the colour. FORS (fibre optic reflectance spectroscopy) was employed to investigate the chemical nature, the oxidation state and the coordination of the chromophores. XPS (X-ray photoelectron spectroscopy) was here exploited for characterising the outermost layers of the glasses. By elemental analyses ( $\mathrm{pXRF}$ and SEM-EDX) it has been pointed out that $\mathrm{Si}, \mathrm{Fe}, \mathrm{Al}, \mathrm{Ca}, \mathrm{K}, \mathrm{Rb}, \mathrm{Sr}, \mathrm{Na}$ and $\mathrm{Mg}$ are the main elements present. The chromophores responsible for the different shades are Fe for the green shades, $\mathrm{Cu}$ and $\mathrm{Co}$ for the blue ones, Mn (used also as discolouring agent) for the colourless samples. In relation to the raw materials used for glass production, the comparison with control groups of samples from Northern Tunisia suggests a common provenance of sands. 
July 21, 2015

Dear Editor,

I would like to submit for publication in Microchemical Journal for the special Issue Technart 2015, the paper entitled:

Characterisation of Roman and Byzantine glasses from the surroundings of Thugga (Tunisia): raw materials and colours

Authors: P. Fermo*, M. Andreoli, L. Bonizzoni, M. Fantauzzi, G. Giubertoni, N. Ludwig, A. Rossi * corresponding author

This is an original paper, which has neither previously, nor simultaneously, in whole or in part been submitted anywhere else. The paper deals with the study of Roman and Byzantine glass shards coming from the ancient city of Thugga in northern Tunisia, particularly flourishing during the Roman and Byzantine periods. Techniques such as SEM-EDS and pXRF (portable X-Ray Fluorescence) were used to determine the glass matrix elemental composition, to identify the nature of the flux and to highlight the elements responsible for the colour. FORS was employed to investigate the chemical nature, the oxidation state and the coordination of the chromophores while XPS was here exploited for characterising the outermost layers of the glasses. The results obtained allow to hypothesize that local production centres were active in Northern Tunisia in this period. In conclusion the present study contributes to improve the knowledge concerning the still open question of glass production in the Roman and Byzantine period.

We believe the subject of the paper is coherent with the topics of your journal and in particular with the topics of this special issue. For this reason we hope our submission will be favourably considered for the publication.

We look forward to your reply,

Kind Regards,

Paola Fermo and co-Authors. 
The paper entitled:

Characterisation of Roman and Byzantine glasses from the surroundings of Thugga (Tunisia): raw materials and colours

reports a complete study form the archaeometrical point of view of Roman and Byzantine glass shards coming from the ancient city of Thugga in northern Tunisia, particularly flourishing during the Roman and Byzantine periods. The provenance of the raw materials, the flux added and the chromophores responsible for the different colour shades have been investigated. The results obtained allow to hypothesize that local production centres were active in Northern Tunisia in these periods. The examined shards are quite homogeneous with respects to some glasses reference groups already published in the literature even if some different recipes were employed for the obtainment of the different colours. The present study contribute to improve the knowledge concerning the still open question of glass production in the Roman and Byzantine period. 


\title{
Characterisation of Roman and Byzantine glasses from the surroundings of Thugga (Tunisia): raw materials and colours
}

\author{
P. Fermo*, M. Andreoli, L. Bonizzoni, M. Fantauzzi, G. Giubertoni, N. Ludwig, A. Rossi \\ Dipartimento di Chimica, Via Golgi 19, Università degli Studi di Milano, Milano \\ Dipartimento di Lettere e Filosofia, via Tommaso Gar 14, Università di Trento, Trento \\ Dipartimento di Fisica, Via Celoria 16, Università degli Studi di Milano, Milano \\ Dipartimento di Scienze Chimiche e Geologiche S.S. 554 bivio per Sestu, Università degli Studi di Cagliari, \\ Monserrato (Cagliari) \\ Corresponding author: paola.fermo@unimi.it
}

\begin{abstract}
Roman and Byzantine glass shards collected during excavation campaigns around the ancient city of Thugga in northern Tunisia have been characterised by means of various analytical techniques. pXRF (portable XRay Fluorescence) and SEM-EDX (scanning electron microscopy coupled with energy dispersive X-ray analysis) were used to determine the glass matrix elemental composition and to identify the elements responsible for the colour. FORS (fibre optic reflectance spectroscopy) was employed to investigate the chemical nature, the oxidation state and the coordination of the chromophores. XPS (X-ray photoelectron spectroscopy) was here exploited for characterising the outermost layers of the glasses. By elemental analyses (pXRF and SEM-EDX) it has been pointed out that $\mathrm{Si}, \mathrm{Fe}, \mathrm{Al}, \mathrm{Ca}, \mathrm{K}, \mathrm{Rb}, \mathrm{Sr}, \mathrm{Na}$ and $\mathrm{Mg}$ are the main elements present. The chromophores responsible for the different shades are Fe for the green shades, $\mathrm{Cu}$ and $\mathrm{Co}$ for the blue ones, $\mathrm{Mn}$ (used also as discolouring agent) for the colourless samples. In relation to the raw materials used for glass production, the comparison with control groups of samples from Northern Tunisia suggests a common provenance of sands.
\end{abstract}

Keywords: Late antique glass; Tunisia; elemental composition; XRF; XPS; FORS 


\section{Introduction}

The analysis of ancient glasses provides useful information concerning both provenance and production technology. In Roman times glass was produced from its raw materials in so - called 'primary' workshops based upon quartz sand with a soda-rich mineral flux (natron) and lime bearing material, shell or limestone [1-2]. Some specialists proposed that lime and silica were generally introduced into the Roman glass through a single raw material, i.e. coastal sands or river mouth sand deposits where the two materials were intimately mixed together in the optimal ratio to produce the glass.

The obtained raw glass was broken into blocks and traded throughout the Mediterranean, where it was remolten, shaped into vessels or other objects and coloured in 'secondary' workshops. So far 'primary' production centres, active at least from the end of the $1^{\text {st }}$ century $\mathrm{BC}$ to the $7^{\text {th }}-8^{\text {th }}$ century, were identified in Egypt around Maryut lake (near Alexandria) and in the region of Wadi el Natrun, and along the SyroPalestinian coast. Nevertheless, the location of primary glass production in the Hellenistic and early Roman world is still debated and some authors have suggested places outside Egypt and the Levant [3-4]. According to the Latin author Pliny the Elder, also sands from the coasts of Italy, nearby Naples (Plinius Secundus, Naturalis Historia 36, 66, 194) and from the mouth of the river Belus, now called Na'aman River, south of Acre in Israel (Plinius Secundus, Naturalis Historia 36, 65, 190) were suitable to make the glass.

In any case natron was added to the sand as source of alkali (Plinius Secundus, Naturalis Historia 36, 65, 191) in order to lower its melting point. This substance, generated by phenomena of periodic evaporation of the brackish (salmastra) water of some lakes, was present in the ancient regions of Media, Thrace and especially in Macedonia, Egypt and Lydia (Plinius Secundus, Naturalis Historia 31, 46, 106-113). From these sites natron was exported to other glass production centres, where it was not naturally available. From the point of view of the chemical composition natron is a mixture of sodium carbonate, sulphate and chloride in quite variable ratios. However around $800 \mathrm{AD}$ a great change in the glass chemical composition occurred, when natron was replaced by plant ash (potash), which contains potassium instead of sodium as alkali source [5-6]. 
Roman and Byzantine glasses generally show a good standard of technology, particularly in terms of colour control. Transition metal ions, such as iron $\left(\mathrm{Fe}^{3+} / \mathrm{Fe}^{2+}\right)$, cobalt $\left(\mathrm{Co}^{2+}\right)$ and copper $\left(\mathrm{Cu}^{2+} / \mathrm{Cu}^{+}\right)$acted as colouring agents in the glass production process [2]. Often iron was not voluntarily introduced but already present in the raw material as impurity. This element can be present in different oxidation states: oxidized $\left(\mathrm{Fe}^{3+}\right.$, lightly coloured in yellow), semi-reduced (approximately equivalent amounts of $\mathrm{Fe}^{2+}$ and $\mathrm{Fe}^{3+}$, coloured in green blue) or reduced $\left(\mathrm{Fe}^{2+}\right.$ characterised by an intense yellow-amber or green-yellow colour). So, since the iron impurity was assumed to derive from the sand, when possible, low-iron high purity sands were selected for the manufacture of colourless glass production (Plinius Secundus, Naturalis Historia 36, $66,194)$.

Colourisers and de-colourisers were skilfully used, in conjunction with the control of furnace parameters to provide a wide variety of hues. In many cases manganese and antimony were used to lower the saturation of the colour in Roman glasses, as they are iron oxidant [7]. The purest naturally occurring manganesecontaining mineral is pyrolusite $\left(\mathrm{MnO}_{2}\right)$ and some authors suggest that it could have been accidentally added as contaminant of the raw materials or as a result of recycling glass. Whenever its concentration is above $1 \%$, it is generally considered an intentional addition [8].

As already acknowledged, colours and shapes of glass objects can provide important information for distinguishing features of specific production centres and periods. Different historical periods reflect traditions, tastes, styles, and technology progresses of people in the fabrication of characteristic artefacts, which are undeniably related to the raw material sources found in each territory. The present investigation focuses on glass objects discovered in an area around the ancient city of Thugga in northern Tunisia, particularly flourishing during the Roman and Byzantine periods. Beyond the advantageous position in the south of the Medjerda plain, whose argillaceous terrains and sand deposits stimulated the Roman pottery production, it also benefitted from a balanced agricultural land exploitation, well-functioning road networks and active trading-systems introduced during the early Roman period. Concerning the glass production and distribution, the Late Roman-Byzantine time is no longer characterised by elaborate vessel shapes derived from precious metal prototypes, but rather by simpler multifunctional forms, as beakers, goblets, and dishes 
with similar features in the whole Mediterranean world. Also the glass composition seems to change between the $4^{\text {th }}$ and the $5^{\text {th }}$ century, turning to a yellowish-green or olive green colouration of the glass instead of the typical Roman blue-greenish colouration of earlier times. This new glass colouration varies further drastically in the $7^{\text {th }}$ century, when a characteristic light blue-turquoise glass becomes the most widespread. In the last twenty years the researchers are trying to combine archaeological and chemical information for ascertaining the origin of the raw materials and understanding the level of technological knowledge of the ancient glassmakers.

The abundant Tunisian glass assemblages of Late Roman-Byzantine period from excavations or surveys are very interesting in this sense, even though not yet accurately published. The proposed analyses on a new group of shards will therefore enhance the current knowledge about glass production in this territory, using some fundamental published studies as guidelines.

Chemical analyses support archaeological research examining the composition of used raw materials, the percentages of their mixtures and their influence in the colourisation process. The techniques applied in the present study for the characterisation of a group of 39 glass shards from Aïn Ouassel and Thugga area were: p-XRF (X-ray photoelectron spectroscopy) and SEM-EDX (scanning electron microscopy coupled with energy dispersive X-ray analysis) to investigate the elemental composition and to acquire information on both raw materials and chromophores elements, FORS (fibre optic reflectance spectroscopy) for the identification of the chromophores elements and XPS (X-ray photoelectron spectroscopy) for the identification of their chemical states and to ascertain the composition of the glass surfaces.

\section{Materials}

\subsection{Analysed samples}

The studied glass shards were collected on an area of about $372 \mathrm{~km}^{2}$ in the surroundings of the ancient city of Thugga, in northern Tunisia, during survey and excavation campaigns carried out between 1994 and 2008 by Trento University (project dir. Prof. M. de Vos) [9-10]. The majority of the analysed fragments belong to the glass assemblage of a Roman-Byzantine farm excavation at Aïn Ouassel [11] while a lower amount of 
samples is represented by surface findings from some mapped ancient sites (Fig. 1). The first mentioned group has the advantage of a stratigraphic context, which simplifies typo-chronological identification of attested vessel forms. Surface findings, instead, are more difficult to interpret, especially because of their fragmentary status and the long occupation of Tunisian rural sites. The twenty-eight analysed excavation samples (Fig. 2) were chosen among 132 glass fragments belonging to 56 objects, which reflect the common uses for Late Antiquity and the Byzantine period. According to the documented record the Aïn Ouassel assemblage can be chronologically defined as in the following: dishes and bowls were probably dated to the $4^{\text {th }}-5^{\text {th }}$ century productions as the well-known olive green beakers; other types of beakers could circulate until the $7^{\text {th }}$ century; stemmed goblets of greenish-yellow colour were produced during the $6^{\text {th }}$ century, light blue ones during the $7^{\text {th }}$ century.

Eleven samples collected on some of the 641 mapped sites in the surroundings of Thugga have also been selected for the analyses. Out of them only two can be typologically compared with the Late RomanByzantine excavation samples, while the rest sensibly differs in terms of forms and chronology, concerning in fact typical Roman productions of the $2^{\text {nd }}-3^{\text {rd }}$ century. The heterogeneous group of selected samples from excavation and survey permits to have a larger range of variables to analyse and compare.

All the examined samples are reported in Table 1, together with the sample description, colour and dating period. The most represented colours are olive green ( 7 samples from the excavation), shades between light green and light yellow (17 samples, 15 from the excavation and 2 from the survey) and light blue (5 samples, 2 from the excavation and 3 from the survey). Furthermore deep green, deep blue, colourless and one violet glass are present.

\section{Applied techniques}

\subsection{Portable X-ray fluorescence ( $p X R F)$}

XRF analysis was performed using a SPECTRO XRF handheld analyser (max parameters: $50 \mathrm{kV}, 125 \mu \mathrm{A}$, 2,5 W) equipped with high-resolution silicon drift detector (SDD) and Rh anode X-ray tube with $3 \mathrm{~mm}$ focal spot on the sample. To get XRF spectra and quantitative evaluation, a modified Mining method (see the user 
manual of SPECTRO xSORTXHH03 handheld EDXRF spectrometer) was used, where the list of considered elements was customized for this kind of materials. This method considers two consecutive acquisitions (40 kV, $50 \mu \mathrm{A}$ and $20 \mathrm{kV}, 125 \mu \mathrm{A}$, respectively) to obtain more accurate results for both light and medium-heavy elements. Preliminary analyses were performed on two certified glass reference standards made by Stazione Sperimentale del Vetro (Venice, Italy) to conveniently set the method parameters. The calculation considered 47 elements with $\mathrm{Z}$ between $12(\mathrm{Mg})$ and $92(\mathrm{U})$, being twenty among them below the detection limits the concentrations were thus determined for $\mathrm{Mg}, \mathrm{Al}, \mathrm{Si}, \mathrm{P}, \mathrm{S}, \mathrm{Cl}, \mathrm{K}$, Ca, Ti, V, Cr, Mn, Fe Co, Ni, Cu, Zn, As, Zr, Rb, Sr, Y, Ag, Sb, W and Pb, but only eight elements (Table 2) were substantial to draw conclusions about glassy matrix and chromophores.

\subsection{Fibre optic reflectance spectroscopy (FORS)}

Measurement of both reflectance and transmittance spectra in visible - NIR wavelengths (380-1000 nm) was used to objectively determine the colour of the examined samples. Due to irregularity of sample surface, an innovative technique of optical characterisation was set up for the samples where no surface enough for stable probe measurements was available. Portable spectrophotometer (HR4000, Ocean Optics ${ }^{\circledR}$, Dunedin, FL, USA) was calibrated to a reflectance standard (white Spectralon ${ }^{\circledR} 99 \%$ ) and connected to a laptop for data acquisition and software analysis. It detected light in the range visible and near infrared bands up to $1100 \mathrm{~nm}$, reflectance data was recorded every $2.7 \mathrm{~nm}$. Measurements were carried out using both a halogen light source (HL2000, Ocean Optics ${ }^{\circledR}$, Dunedin, FL, USA) - with a cyan filter apt to enhance the blue component of the source and to improve the signal to noise ratio. Furthermore in the $380-420 \mathrm{~nm}$ range a high power Xenon lamp was used. Light was transmitted by a $1 \mathrm{~m}$ long quartz fibre optics bundle with a diameter of $400 \mu \mathrm{m}$ (Ocean Optics ${ }^{\circledR}$ Dunedin, FL, USA), connected to the probe. Two different probes were used: a thin tubular coaxial probe (length $=10 \mathrm{~cm}$, diameter $1 \mathrm{~cm}$ ) in $45^{\circ}$ x $45^{\circ}$ geometry and an integrating hosting chamber in transmission mode. Areas to be analysed were not greater than about $1 \mathrm{~cm}^{2}$ and measurement problems might arise from event related to the variation of the beam path in the fibre optics and their connections. A preliminary study was therefore specifically addressed in regards to measure the stability with the change in the arrangement of optical fibres [12]. In the second experimental set up 
(transmission mode trough an integrating chamber) when the sample surface did not exhibit enough flat areas to obtain a representative spectrum of the optical property of the surface, it was inserted in an aluminium chamber where the sample was housed and where the light passes through avoiding any lack. In this case the baseline was measured by placing a $\mathrm{BaSO}_{4}$ tablet in the chamber to avoid any direct transmission of the light beam through the chamber. In this way, the optical throughput depends on the interaction with virtually all surfaces of the sample put into the reflectance chamber. In order to avoid influence of geometry setup the spectra considered in this work were averaged over ten different acquisitions in different days [12].

\subsection{Scanning electron microscopy coupled with energy dispersive X-ray analysis (SEM-EDX)}

The shards were analysed by SEM-EDX (scanning electron microscopy coupled with energy dispersive Xray analysis) to obtain information on the chemical composition. The instrument used was a Hitachi TM1000 equipped with an energy dispersive X-ray Spectrometer (Oxford Instruments SwiftED). The spectra were directly acquired on the glass shards attached to the sample holder by adhesive tape.

\subsection{X-ray photoelectron spectroscopy (XPS)}

X-ray photoelectron spectroscopy analyses were carried out using a Theta Probe (Thermo Fisher Scientific, Waltham MA, USA). The samples were characterised in the as received state and after 10 seconds of sputtering to gently remove the thick organic layer that attenuated the photoelectrons from the glasses. They were assembled on a standard sample holder for XPS measurements with copper clips. Spectra were collected using a $300 \mu \mathrm{m}$ monochromatic beam $\left(\mathrm{Al} \mathrm{k} \alpha_{1,2}\right.$ energy $\left.=1486.6 \mathrm{eV}\right)$ operated at $4.7 \mathrm{~mA}$ and 15 $\mathrm{kV}$. A flood gun was used for charge compensation. Survey and high-resolution spectra were acquired in fixed analyser transmission mode (FAT) setting the pass energy (PE) at $200 \mathrm{eV}$ and at $100 \mathrm{eV}$ respectively selecting the standard lens mode. The full-width at half-maximum of the peak height, FWHM, of the silver $\operatorname{Ag} 3 \mathrm{~d}_{5 / 2}$ signal for the high-resolution spectra was $0.83 \mathrm{eV}$. The residual pressure in the main chamber was lower than $10^{-7} \mathrm{~Pa}$. The adventitious aliphatic carbon at $285.0 \mathrm{eV}$ was chosen as internal reference. Data were acquired under computer control (Avantage v 3.45). 
The spectra were processed using CASAXPS software - version 2.3.16 PR1 (Casa Software Ltd., Wilmslow, Cheshire, UK) [13]. An iterated Shirley - Sherwood background [14] was subtracted before curve fitting. The product of Gaussian and Lorentzian functions was used for curve fitting. Quantitative composition was calculated using the first-principle method [15] under the assumption that the samples were homogeneous in composition. Peak areas were corrected for the sensitivity factors using Scofield's photoionization cross-sections $\sigma$ [16] corrected for the asymmetry parameter [17], the inelastic mean free paths (IMFP) and the intensity/energy analyser response whose details are reported in literature [18].

\section{Results and discussion}

\subsection{Raw materials: sands and flux}

The samples were first analysed by pXRF (portable X-Ray Fluorescence) to investigate the glass matrix elemental composition and to identify the responsible components in colouration.

It is worth noting that a non-destructive technique, such as XRF, has been applied in our case since it was not possible to destroy most of the glass shards. In table 2 the chemical composition of the analysed glasses is reported for what concerns the main elements. Taking into account that XRF cannot detect element with Z less than 13 (such as $\mathrm{Na}$ and $\mathrm{Mg}$ ), the glass matrix mainly contains $\mathrm{Si}, \mathrm{Fe}, \mathrm{Al}, \mathrm{Ca}, \mathrm{K}$, Ti, Mn and P; SEMEDX revealed the presence of $\mathrm{Na}$ and $\mathrm{Mg}$.

The obtained compositional data ware compared with well-established glass composition groups already published in the literature to investigate the provenance the ancient glass matrix. Some glasses from sites located on the north-eastern Tunisian coast (Nabeul, Sidi Jdidi, Oued'Rmel) and subdivided by glass specialists $[19,20]$ on the basis of their colours and chronologies in compositional group 1 (olive green colour; $5^{\text {th }}$ century), group 2 (greenish-yellow; $6^{\text {th }}$ century) and group 3 (light blue; $7^{\text {th }}$ century), were used as principal reference samples.

From $\mathrm{CaO} / \mathrm{SiO}_{2}$ ratio it results that most of the samples coming from the surroundings of Thugga, and in particular from Aïn Ouassel, are quite homogeneous witnessing the choice of the same raw clay. A lower 
$\mathrm{SiO}_{2}$ content (see Table 2) is characteristic of a group of Aïn Ouassel samples suggesting a probable different raw material supply or a partial depletion in Si content due to some glass degradation phenomenon.

As far as the sand choice is concerned some specific places were indicated by historical sources [1]. However, looking at the Mediterranean basin and its geology, it can be observed that about 54\% of its coastline is rocky while the remaining $46 \%$ consists of various sedimentary accumulation [21] in form of sandy beaches, estuaries, deltas, etc. In particular among the largest deltas, together with the Nile in Egypt, Rhone in France, Po in Italy, and many others, there is also the Medjerda in Tunisia. It might be supposed that this north African river, the ancient Bagradas, mentioned by numerous Latin and Greek poets and historians for its importance in the agricultural development of this territory and the relevant position of its delta between the cities of Utica and Carthage, supplied also the sand for a local glass production, even though ancient glass furnaces are still unknown in the studied area.

Principal component analysis (PCA) (Fig. 3) was carried out on the compositional data reported in table 2 and has evidenced how a large number of samples from Aïn Ouassel and the surroundings of Thugga are homogeneous with respect to the samples of the three reference groups mentioned above. It is worth noting that the variance explained by the first two components is larger than $98 \%$. The outstanding samples have been evidenced in the figure by their name. Sample n. 43 represents a unicum amongst the analysed glass shards (belonging mostly to goblets and beakers), as a probable body fragment of a ribbed flask. Its slightly green colour and thinness are in fact similar to fragment n. 48 (both from the excavation), until now appertaining to an unidentified object, but maybe belonging to a second flask. Shard n. 49 of brilliant blue colour (unidentified vessel form) was already identified as different by a simple optical analysis. The better fabric and colour quality of this glass does not correspond to the other ones, which will be highlighted further. For what concerns samples n. 29 (rim of goblet) and n. 39 (rim of lamp), it might be remarked only that at first sight they seem a little brighter than the other light blues. Especially the lamp fragment is nearly colourless. The analysed yellowish $1^{\text {st }}-2^{\text {nd }}$ century cup fragment does not reveal particular differences with regard to the yellowish Byzantine goblet shards and lies in the big central sample aggregation. Nevertheless, the yellowish/greenish group, as evidenced by the graph, is not homogeneous, and in particular samples $\mathrm{n}$. 
13, 22 and 36 are grouped together, outside the main cluster. To better evidence differences among samples a new PCA was carried out (results not shown) on the data set and it provided evidence that the shards 13 , 22, 36 show a high manganese, iron and titanium content.

Reference group 1 belongs to the so-called HIMT glasses (with High Iron, Manganese and Titanium concentrations) defined for the first time by I. Freestone [7, 22]. This kind of glass became widespread in the Mediterranean regions late in the $4^{\text {th }}$ century or early in the $5^{\text {th }}$ century AD. Specialists initially interpreted its characteristic colour as an involuntary production failure, but in the last years, the abundance of analyses on these samples reveals even more an Egyptian provenance of the raw glass, which was remolten in several secondary furnaces throughout the Late Roman world [23]. HIMT glass analyses demonstrated that it was either produced mixing two different types of sand: one rich in $\mathrm{FeO}, \mathrm{TiO}_{2}, \mathrm{Al}_{2} \mathrm{O}_{3}, \mathrm{MgO}$ and $\mathrm{MnO}$ and another rich in $\mathrm{CaO}$. They might be also obtained by recycling broken vessel glasses, which was a quite common practice at that time.

The bi-plot $\mathrm{TiO}_{2}$ vs $\mathrm{Fe}_{2} \mathrm{O}_{3}$ (Fig. 4a) shows that olive green samples from Aïn Ouassel are characterised by a slightly higher Ti content with respect to the olive green (HIMT) samples belonging to group 1 [19, 20]. This demonstrates the existance of a small variability between the compostions. The olive green samples from the Aïn Ouassel excavation seem rather homogeneous and it might suggest the same production center provenance. Only the dish fragment n. 478.2 of Roman time (approximately to date between the $2^{\text {nd }}$ and the $4^{\text {th }}$ century) found on surface near Thugga differs from the rest of olive green shards (Fig. 4b). It is interesting because its colour seems optically similar to the other analysed samples, belonging to beakers and a goblet of the $5^{\text {th }}-6^{\text {th }}$ century, but it is clear that its composition substantially deviates from the Late Roman and Byzantine glasses.

The greenish yellow shards, bearing a lower Ti content, fit quite well with reference group 2 with the exception of two samples, shards n. 22 and n. 43, also characterised by a higher Mn content (Fig. 5). The same happens for the light blue samples. Most of them are very similar to reference group 3 (see in particular the enlargement in Fig. 4b), although they show a slightly higher Mn content (Fig. 5). 
XRF was not able to quantify sodium amount in the flux while semi-quantitative data were available by SEM-EDX analyses. The concentrations detected in our case are lower than those reported for typical sodalime-silica glasses [24] and soda ash-glass, the most diffused typologies in the Mediterranean basin [25]. Low values of sodium concentration might be also ascribed to degradation phenomena clearly detectable in most of the samples and in agreement with Barbera et al. [26]. On the basis of this evidence, the $\mathrm{CaO}_{2} \mathrm{~K}_{2} \mathrm{O}$ and $\mathrm{K}_{2} \mathrm{O} \backslash \mathrm{CaO}$ ratios, together with $\mathrm{CaO} \%, \mathrm{~K}_{2} \mathrm{O} \%$ and $\mathrm{SiO}_{2} \%$ may be used to distinguish among the three possible fluxes employed (i.e. natron, plant ash and wood ash) [27, 28].

For example, $\mathrm{CaO} \backslash \mathrm{K}_{2} \mathrm{O}$ ratio higher than 16 is typical of natron glasses while a ratio lower than 1.7 is due to plant ashes; in particular a ratio lower than 0.88 is referred to the use of wood ash.

The comparison of $\mathrm{CaO} \backslash \mathrm{K}_{2} \mathrm{O}$ ratios calculated for our samples (Fig. 6) with those of the literature [27, 28] allows assessing that natron might be only used for seven glasses. It is worth noting that some of these samples are unique types in the assemblage, as mentioned for example above for the blue shard n. 49 . This demonstrates again the different origin of the glass object. It should be highlighted that the dish fragments $n$. 1 and n. 2, despite the identic shape and chronology, are very different in the histogram: the first one is characterized by a very high natron content while the second is apparently a mixture with a low natron content. It might therefore be suggested that the raw glass was produced in different centres. The light yellow n. 22 and light green n. 48, as already stated, are very different in respect to the other similar coloured fragments. Even though the first one (goblet rim) does not reveal clear visible differences related to the other goblets, its production does not evidently follow the same technique as the other ones (see further). Sample n. 634 of turquoise/light blue colour, which was found on the surface of a site located $20 \mathrm{~km}$ to the east of Aïn Ouassel, was attributed to a stemmed goblet of the $7^{\text {th }}$ century. The results obtained on the 4 turquoise samples (n. 634, n. 59, n. 29 and n. 37) exhibit a very different natron content: they are either characterised by a high natron content or low/absent natron. Figure 7 shows that plant ash was only used for the unidentified sample of site 59 while for all the other fragments it can be proposed a mixture of natron and plant ash, as also attested in the literature by Gallo et al. [27].

\subsection{Glass colour}


The chemical nature of chromophores can be investigated by means of UV-vis-NIR (Ultraviolet -Visible

- Near Infrared) reflectance spectroscopy (Fibre optic reflectance spectroscopy, FORS) both in reflectance and transmission mode (depending on the sample colour and transparency). Achievable information from reflectance spectra are linked to properties of light reflection, which results in a chemical and chromatic characterisation of the gems. This kind of analysis, not so much used on amorphous transparent materials, provides indeed a huge amount of information about both chromophore and glassy matrix constituent [29, 30, 31]. Moreover in some cases the position of absorption bands in FORS spectra is affected by the vitreous matrix, as it will be highlighted in the following [32].

It is not easy to give an unambiguous definition of colour for the samples studied, mostly for the greenishyellow ones. This reflects in the variety of the composition as concerns both Fe oxidation states and Mn content. For the sake of simplicity, in the following, five glass classes will be considered: 1) yellow and light green; 2) blue; 3) light blue, light yellow and colourless; 4) green; 5) purple. On the basis of Table 2 some comments can be done about colouring and decolouring agents.

\subsubsection{Yellow and light green glasses}

In iron oxides iron can be present as $\mathrm{Fe}^{2+}$ and $\mathrm{Fe}^{3+}$ depending on melting and cooling conditions: temperature and oxygen partial pressure of the atmosphere and batch. In fact, iron is the major colouring impurity present in natural sands affecting the optical properties of the glasses.

It is possible to find a relation between the iron concentration ratio in the two-oxidation states, the presence of manganese oxide and the glass colour [24]. $\mathrm{Fe}^{3+}$, which is acknowledged to be responsible for the yellow colouring, can have both octahedral and tetrahedral configuration. These can be identified since the first has a broad band at 280-340 $\mathrm{nm}$ while the second is characterised by a band at $380-420 \mathrm{~nm}$. Thus the spectrum of Fig. 8 provides evidence that iron is here present as $\mathrm{Fe}^{3+}$ in a tetrahedral configuration.

$\mathrm{Fe}^{2+}$, responsible for the blue colouring, is also present as demonstrated by the broad band that starts to increase at $950 \mathrm{~nm}$ corresponding to the octahedral configuration.

When both redox states are present, the glass assumes a yellow-greenish hue depending on the value of the ratio. As already stated, melting conditions might influence the $\mathrm{Fe}^{2+} / \mathrm{Fe}^{3+}$ ratio and it was demonstrated that 
green, blue, and amber hues are obtainable starting from similar sands just controlling the firing conditions [40].

X-ray photoelectron spectroscopy analyses, that are proven to be a useful tool to investigate the surface composition and the chemical state of chromophores of glasses of archaeological interest [33], confirm the presence of both $\mathrm{Fe}^{2+}$ and $\mathrm{Fe}^{3+}$ on the surfaces of yellow and light green glasses. The curve fitted $\mathrm{Fe} 2 \mathrm{p}_{3 / 2}$ signal of sample n. 22 (Fig. 9) shows the presence of three components that, according to literature [18, 33, 34, 35, 36, 37, 38, 39] might be assigned to Fe (II) and Fe (III) surrounded by oxygen atoms and to Fe (III) in oxy-hydroxide species. In details: Fe (II) - O is found at $709.0(0.2) \mathrm{eV}, \mathrm{Fe}(\mathrm{III})-\mathrm{O}$ at $710.6 \mathrm{eV}(0.2) \mathrm{eV}$ and $\mathrm{Fe}-\mathrm{OOH}$ at $711.8(0.2) \mathrm{eV}$.

Chemical composition in terms of weight concentration of metallic elements is very variable in this class. FORS spectra indicated high $\mathrm{Fe}^{3+}$, mainly in tetrahedral configuration: due to the bandwidth $\mathrm{MnO}$ cannot be detected (Mn is often present above 1\%). Among yellowish glasses, n. 22 seems to be peculiar, also showing no-negligible cobalt content. As far as this sample is concerned, also XPS analyses confirm the presence of about 0.2 at $\%$ of Co together with about $1 \%$ of Mn (Fig. 10). Furthermore both the lack of potassium signals and the presence of $\mathrm{Na}(2 \mathrm{at} \%)$ confirm the hypothesis that natron was used as a flux to produce this glass, in agreement with Fig. 7.

\subsubsection{Blue glasses}

Cobalt is the well-known metal responsible for deep blue coloration; it has a very high colouring power, so small concentrations can be easily detected. On the other hand, it is difficult to reveal and quantify cobalt by $\mathrm{XRF}$ when iron is present in not negligible amounts since Co K $\alpha$ emission is hidden by Fe $\mathrm{K} \beta$ line. The presence of cobalt oxide can instead be easily seen in FORS spectra due to three characteristic absorption bands (540-590-640 $\mathrm{nm}$ ) which can be shifted towards lower wavelengths (first band at $526 \mathrm{~nm}$ ) in presence of potash glass matrix [29]. Moreover, the cobalt used to produce ancient glasses could be an impurity in iron and nickel rich minerals so that iron and nickel presence must also be considered together with cobalt. Two samples (Fig. 11) show a deep blue colour (550.1 and 550.2) and have a higher copper and cobalt content. Furthermore, the already mentioned particular light blue sample n. 49 is also characterised by 
containing more copper and cobalt, high-lead level and low-iron amount. The presence of copper and cobalt was also confirmed by XPS analyses (Fig. 12), together with iron that was only present as $\mathrm{Fe}^{3+}$ (Fig. 13) as confirmed by the absence in the spectrum of the component at $709.0 \mathrm{eV}$. Due to the poor signal to noise ratio under the chosen experimental conditions, the curve fitting of $\mathrm{Cu} 2 \mathrm{p}$ and $\mathrm{Co} 2 \mathrm{p}$ signals was not attempted. No lead was detected in the outer region of this sample. To verify the presence of lead in depth without compromising the integrity of the sample, the section was also analysed and its composition did not significantly differ from the surface of the sample (supporting information S-fig.1).

FORS spectra of these three blue samples confirm the presence of cobalt as chromophore (see Fig. 11) and the position of absorption bands substantiates that it has a soda - based vitreous matrix [29]. Further, sample n. 49 exhibits a different spectrum in the NIR region: the peak linked with the $\mathrm{Fe}^{3+}$ absorption at $320 \mathrm{~nm}$ is more intense and it is better defined than in the case of samples of site 550.

These differences can be ascribed to the composition of the starting cobalt-bearing mineral. The different composition indicates a different origin of the raw material, and/or a diverse production technique.

Other two fragments show cobalt presence: the yellow sample n. 22, as mentioned before, and the light greenish-colourless n. 2. Cobalt bearing minerals used at the time, contained nickel impurities that might provide some further information. The only nickel containing samples are those containing cobalt, too. Table 3 lists the nickel to cobalt ratio for nickel bearing samples: samples 550.1 and 550.2 having almost the same ratio, and n. 22, which reveals a very high nickel content indicating a different origin for the mineral used.

\subsubsection{Light blue, light yellow and colourless glasses}

In the Roman period, colourless glasses were produced by adding either antimony or manganese oxide. The latter oxidises iron (II) oxide to iron (III) oxide, which although yellow, is a much weaker colorant, allowing the glass to appear colourless.

Some other samples have a light blue shade: in this case the presence of a mixture of $\mathrm{Fe}^{2+}$ and $\mathrm{Fe}^{3+}$ with the addition of $\mathrm{Mn}$ that compensates the green due to $\mathrm{Fe}$, can be exploited to explain this colour. $\mathrm{Mn} / \mathrm{Fe}$ ratio is found to be close to 1 for light blue samples, while it is higher than 1 for colourless glasses. However, iron concentration is below the average value with respect to the other samples, indicating the choice of purest 
sand as row material to produce colourless glass objects. A confirm of the low iron content in colourless glasses is provided by XPS spectra for sample n. 39 (lamp fragment) which did not show any iron signal (Fig. 14). Manganese can be present as $\mathrm{Mn}^{2+}$ in the oxide: in this case the absorption in the UV region with a weak band around $430 \mathrm{~nm}$ can be observed. This band might shift towards high wavelengths (about $40 \mathrm{~nm}$ ) if potassium is replacing sodium [41].

\subsubsection{Green glasses}

A variety in the composition of green glasses, and in particular of olive green, can be supposed based on the analytical results: in fact, $\mathrm{Mn} / \mathrm{Fe}$ ratio is slightly variable (see figure 5) while in almost all the green samples a relative high content of $\mathrm{Sb}$ is detected (this element is not shown in Table2). FORS spectra (Fig.15) indicate both $\mathrm{Fe}^{3+}(280-340 \mathrm{~nm}$, octahedral configuration with a broad band; 380 e $420 \mathrm{~nm}$ tetrahedral configuration) and $\mathrm{Fe}^{2+}$ (about $950 \mathrm{~nm}$, octahedral configuration). It is noteworthy that, as shown in fig. 5, different sand was selected for olive green glass production. It is also worth to note that in the case of deep green a more intense band at $380 \mathrm{~nm}$ was observed, as in the case of sample 546, in accordance with a higher iron concentration (Table 2).

\subsubsection{Purple glasses}

The only purple glass is n. 33 from surface at Aïn Ouassel, showing a relative high concentration of both, iron and manganese oxide (about 2 and $3 \%$ respectively) with a ratio $\mathrm{Fe}_{2} \mathrm{O}_{3} / \mathrm{MnO}$ of 0.75 . The FORS spectrum (not reported) shows the absorption bands of $\mathrm{Mn}^{3+}$ (at 470-520 nm) and no iron oxide signals. 


\section{Conclusions}

In this study a group of 39 glass shards dating to the Roman-Byzantine period and coming from the surroundings of the ancient city Thugga in Northern Tunisia has been examined in order to investigate both raw materials provenance and production technology through the identification of the colouring agents and the flux employed. A same origin of the sands can be hypothesized due to the homogeneity of the samples from the compositional point of view. It might be supposed, as already pointed out by D. Foy [20], that local production centres were active at least in Northern Tunisia, where sand deposits of important rivers (Oued Medjerda and Oued Meliane) crossing this territory, were available. Samples revealing instead clear differences in the composition, as noted for some particular shards, may have been imported from elsewhere.

Concerning the flux in most of the cases a mixture of natron and plant ash was used, while natron was used only for 7 samples and plant ash only in one case.

Among the analysed samples from Aïn Ouassel the olive green group is quite homogeneous and shows a higher Ti content with respects to the HIMT reference group. Also greenish-yellow and light blue samples resemble to the reference groups 2 and 3 respectively, even if a higher Mn content has been evidenced in some cases. $\mathrm{Fe}^{2+}$ and $\mathrm{Fe}^{3+}$ are present in the yellow and light green glasses as stated by FORS and XPS measurements, with $\mathrm{Fe}^{3+}$ mainly in the tetrahedral configuration.

Cobalt is the well-known metal responsible for deep blue coloration. Nickel and copper are also present as mineral impurities. By comparing FORS spectra acquired on the blue samples some differences have been highlighted as concerns the presence of $\mathrm{Fe}^{2+}$ together with the typical signals due to cobalt allowing to hypothesize for sample $\mathrm{n} .49$ a different provenance. In the case of light blue shades $\mathrm{Fe}^{2+}$ and $\mathrm{Fe}^{3+}$ are present with the addition of manganese to compensate the green shade; Mn has been employed as decolouring agent but in the case of colourless glasses the lower iron content witnesses the use of a more pure sand to produce these objects.

For the olive green shards $\mathrm{Fe}^{2+}$ and $\mathrm{Fe}^{3+}$ are present in both tetrahedral and octahedral configurations with a variable $\mathrm{Mn} / \mathrm{Fe}$ ratio indicating slightly different recipes for the production of this shade (perhaps an 
intentional addition of $\mathrm{Mn}$ when it is presence in concentration higher than $1 \%$, as already suggested by other authors).

In conclusion the present study contribute to improve the knowledge concerning the still open question of glass production in the Roman and Byzantine periods.

\section{Acknowledgments}

The Institut National du Patrimoine de la Tunisie is thanked for having authorised and kindly supported the Archaeological Mission carried out by Trento University around Thugga.

The Italian Ministry of University and Research (MIUR) is thanked for financing the PRIN project prot. 2010329WPF_005 "Sustainability in cultural heritage: from diagnosis to the development of innovative systems for consolidation, cleaning and protection".

Sardinia Regional Government is gratefully acknowledged for the financial support (P.O.R. Sardegna F.S.E. Operational Program of the Regione Autonoma della Sardegna, European Social Fund 2007 - 2013 - Axis

IV Human Resources, Objective 1.3, Line of Activity 1.3.1 “Avviso di chiamata per il finanziamento di Assegni di Ricerca”. 


\section{References}

[1] A. Silvestri, G. Molin, G. Salviulo, Roman and medieval glass from the Italian area: bulk characterisation and relationships with production technologies. Archaeometry 47(4) (2005) 797-816.

[2] M. Verità, Analisi di reperti vitrei e scarti di lavorazione di tarda età romana provenienti dagli scavi del monastero di Santa Giulia a Brescia, in: G. P. Brogiolo (Ed.), Santa Giulia di Brescia: gli scavi dal 1980 al 1992. Reperti preromani, romani e altomedievali, All'Insegna dell'Giglio, Firenze, 1999, pp. 309-314.

[3] H.E. Foster, C.M. Jackson, The composition of "naturally coloured" late Roman vessel glass from Britain and the implications for models of glass production and supply. J. Archaeol. Sci. 36(2) (2009) 189204. doi:10.1016/j.jas.2008.08.008.

[4] A. Silvestri, G. Molin, G. Salviulo, R. Schievenin, Sand for Roman glass production: an experimental and philological study on source of supply. Archaeometry 48(3) (2006) 415-432.

[5] D. Foy, Composition et propriétés du verre, in: D. Foy (Ed.), Cœur de verre. Production et diffusion du verre antique, InFolio, Gollion, 2003, pp. 16-21.

[6] M. Picon, M. Vichy, D'Orient en Occident: l'origine du verre à l'époque romaine et durant le haut Moyen Âge, in: D. Foy, M.-D. Nenna (Eds.), Échanges et commerce du verre dans le monde antique. Actes du colloque de l'Association Française pour l'Archéologie du Verre en Aix-en-Provence et Marseille 2001, Éditions Monique Mergoil, Montagnac, 2003, pp. 17-32.

[7] I. Freestone, S. Wolf, M. Thirlwall, The production of HIMT glass: elemental and isotopic evidence, in M.-D. Nenna (Ed.), Annales du 16e Congrès de l'Association Internationale pour l'Histoire du Verre, London, 7-13 September 2003, AIHV, Nottingham, 2005, pp. 153-157.

[8] C.M. Jackson, Making colourless glass in the Roman period. Archaeometry 47(4) (2005) 763-780.

[9] M. de Vos (Ed.), Rus Africum. Terra, acqua, olio nell'Africa settentrionale: scavo e ricognizione nei dintorni di Dougga (Alto Tell Tunisino), Labirinti, Trento, 2000.

[10] M. De Vos Raaijmakers, R. Attoui, R. (Eds.), Rus Africum, Tome I. Le paysage rural antique autour de Dougga et Téboursouk: cartographie, relevés et chronologie des établissements. Edipuglia, Bari, 2013.

[11] M. Andreoli, Glass finds from a Late Antique-Byzantine farm at Aïn Ouassel (Tunisia). Antiquités Africaines (forthcoming).

[12] M. Gargano, N. Ludwig, D. Pandini, Use of optical fibre in spectrometry and colorimetry with remote probes. J. Int. Colour Assoc. 8 (2012) 36-43.

[13] N. Fairley, CasaXPS Version 2.3.16: Software package for data processing (2008). Available at http://www.casaxps.com.

[14] D. A. Shirley, High-Resolution X-Ray Photoemission Spectrum of the Valence Bands of Gold. Physical review B 5 (1972) 4709-4714.

[15] M.P. Seah, In Surface Analysis by Auger and X-ray Photoelectron Spectroscopy, D. Briggs and J.T. Grant (Eds.), IM Publication Surface Science Spectra Limited (2003), 354-375 
[16] J. H. Scofield, Hartree-Slater subshell photoionization cross-sections At 1254 and 1487 eV, J. Electron Spectroscopy Relat. Phenom. 8 (1976) 129-137.

[17] R. F. Reilman, A. Msezane, S. T. Manson, Relative intensities in photoelectron Spectroscopy of atoms and molecules, J. of Electron Spectroscopy Relat. Phenom., 8 (1976) 389-394.

[18] M. Fantauzzi, A. Pacella, J. Fournier, A. Gianfagna, G.B. Andreozzi, A. Rossi, Surface chemistry and surface reactivity of fibrous amphiboles that are not regulated as asbestos. Anal. and Bioanal.Chem. 404 (3) (2012) 821-833.

[19] D. Foy, M. Picon, M. Vichy, V. Thirion-Merle, Caractérisation des verres de la fin de l'Antiquité en Méditerranée occidentale: l'émergence de nouveaux courants commerciaux, in: D. Foy, M.-D. Nenna (Eds.), Échanges et commerce du verre dans le monde antique. Actes du colloque de l'Association Française pour l'Archéologie du Verre en Aix-en-Provence et Marseille 2001, Éditions Monique Mergoil, Montagnac, 2003, pp. 41-85.

[20] D. Foy, Le verre en Tunisie: l'apport des fouilles récentes tuniso-françaises. J. Glass Stud. 45 (2003) 59-89.

[21] D. Brems, S. Boyen, M. Ganio, P. Degryse, M. Walton, Mediterranean sand deposits as a raw material for glass production in antiquity, in D. Ignatiadou, A.Antonaras (Eds.), Annales du 18e Congrès de l'Association Internationale pour l'Histoire du Verre, Thessaloniki, 21-25 September 2009, AIHV, Nottingham, 2012, pp. 120-127.

[22] I. Freestone, Appendix: Chemical analysis of "raw" glass fragments, in: H. R. Hurst (Ed.), Excavations at Carthage: The British Mission II, 1. The Circular Harbour, North Side: the site and finds other than pottery, Oxford University Press, Oxford, 1994, p. 290.

[23] D. Foy, Le verre, in: C. Balmelle, A. Bourgeois, H. Broise, J. P. Darmon, M. Ennaïfer (Eds.), Carthage, Colline de l'Odéon: Maison de la Rotonde et du Cryptoportique: Recherches 1987-2000, CEFR 457, Rome, 2012, pp. 765-796.

[24] E. Gliozzo, A. S. Barbone, F. D’Acapito, Waste Glass, Vessels and Window-Panes from Thamusida (Morocco): Grouping Natron-Based Blue-Green and Colourless Roman Glasses, Archaeometry 55 (2013) 609-639.

[25] K.H. Wedepohl, K. Simon, A. Kronz, Data on 61 chemical elements for the characterisation of three major glass compositions in late antiquity and the Middle Ages, Archaeometry 53 (2011) 81-102.

[26] G. Barbera, G. Barone, V. Crupi, F. Longo, D. Majolino, P. Mazzoleni, V. Venuti, Study of Late Roman and Byzantine glass by the combined use of analytical techniques, J. Non-Cryst. Solids 358 (12-13) (2012) 1554-1561.

[27] F. Gallo, A. Silvestri, G. Molin, Glass from the Archaeological Museum of Adria (North-East Italy): new insights into Early Roman production technologies, J. Archaeol. Sci. 40 (2013) 2589-2605.

[28] V. Van der Linden, E. Meesdom, A. Devos, R. Van Dooren, H. Nieiwdorp. E. Janssen, S. Balace, B. Vekemans, L. Vincze, K. Janssens, PXRF, $\mu$-XRF, Vacuum $\mu$-XRF, and EPMA Analysis of Email Champlevé Objects Present in Belgian Museums, Microscopy and Microanalysis 17 (2011) 674-685.

[29] A. Ceglia, W. Meulebroeck, K. Baert, H. Wouters, K. Nys, H. Thienpont, H. Terryn, Cobalt absorption bands for the differentiation of historical $\mathrm{Na}$ and $\mathrm{Ca} / \mathrm{K}$ rich glass, Surf. Interface Anal. 44 (2012) 219-226. 
[30] A. Galli, G. Poldi, M. Martini, E. Sibilia, C. Montanari, L. Panzeri, Study of blue colour in ancient mosaic tesserae by means of thermoluminescence and reflectance measurements, Appl. Phys. A 83 (2006) $675-679$.

[31] P. Mirti, P. Davit, M. Gulmini, Colourants and opacifiers in seventh and eighth century glass investigated by spectroscopic techniques, Anal. Bioanal. Chem. 372 (2006) 221-229.

[32] W. Meulebroeck ; K. Baert ; H. Wouters ; P. Cosyns ; A. Ceglia ; S. Cagno ; K. Janssens ; K. Nys ; H. Terryn ; H. Thienpont, The identification of chromophores in ancient glass by the use of UV-VIS-NIR spectroscopy Proc. SPIE 7726, Optical Sensing and Detection, 77260D (May 13, 2010)

[33] I. Angelini, G. Artioli, P. Bellintani, V. Diella, M. Gemmi, A. Polla A. Rossi, Chemical analyses of Bronze Age glasses from Frattesina di Rovigo, Northern Italy, J. Archaeol. Sci. 31 (2004) 1175-1184.

[35] P. Ballirano, A. Pacella, C. Cremisini, E. Nardi, M. Fantauzzi, D. Atzei, et al., Fe (II) segregation at a specific crystallographic site of fibrous erionite: A first step toward the understanding of the mechanisms inducing its carcinogenicity, Microporous Mesoporous Mater. 211 (2015) 49-63.

[36] M. Fantauzzi, A. Pacella, D. Atzei, A. Gianfagna, G.B. Andreozzi, A. Rossi, Combined use of X-ray photoelectron and Mössbauer spectroscopic techniques in the analytical characterisation of iron oxidation state in amphibole asbestos, Anal. Bioanal. Chem. 396 (2010) 2889-98.

[37] M. Olla, G. Navarra, B. Elsener, A. Rossi, Nondestructive in-depth composition profile of oxyhydroxide nanolayers on iron surfaces from ARXPS measurement, Surf. Interface Anal. (2006) 964-974.

[38] A. Pacella, M. Fantauzzi, F. Turci, C. Cremisini, M.R. Montereali, E. Nardi, et al., Dissolution reaction and surface iron speciation of UICC crocidolite in buffered solution at $\mathrm{pH}$ 7.4: A combined ICP-OES, XPS and TEM investigation, Geochim. Cosmochim. Acta. 127 (2014) 221-232.

[39] A. Pacella, M. Fantauzzi, F. Turci, C. Cremisini, M.R. Montereali, E. Nardi, et al., Surface alteration mechanism and topochemistry of iron in tremolite asbestos: A step toward understanding the potential hazard of amphibole asbestos, Chem. Geol. 405 (2015) 28-38.

[40] W. Hajjaji, K. Jeridi, P. Seabra, F. Rocha, J. A. Labrincha, F. Jamoussi, Composition and properties of glass obtained from Early Cretaceous Sidi Aich sands (central Tunisia), Ceram. Int. 35 (2009) 3229-3234.

[41] W.A. Weyl, Coloured Glass, Society of Glass Technology (1951) 
Click here to download high resolution image

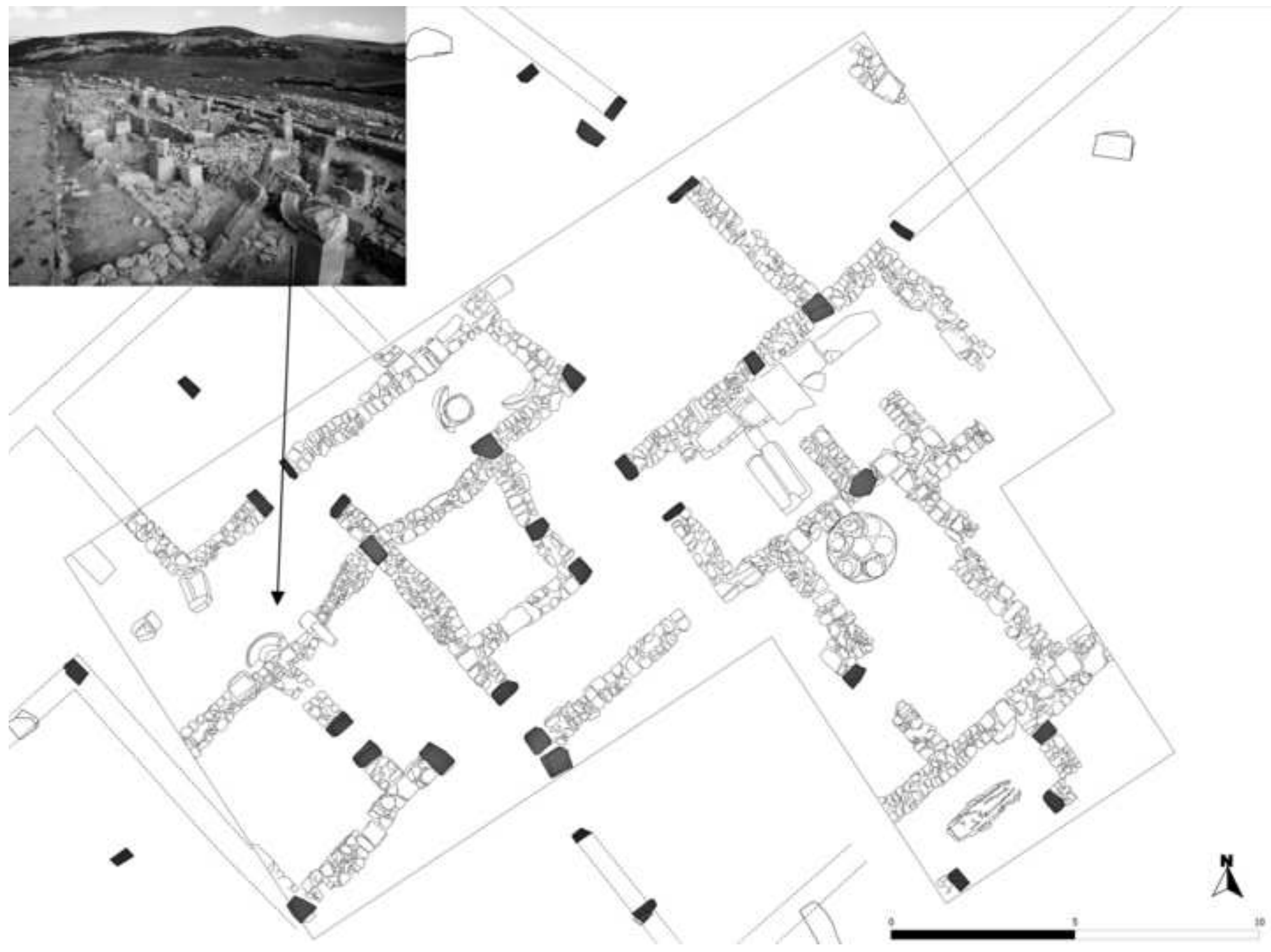




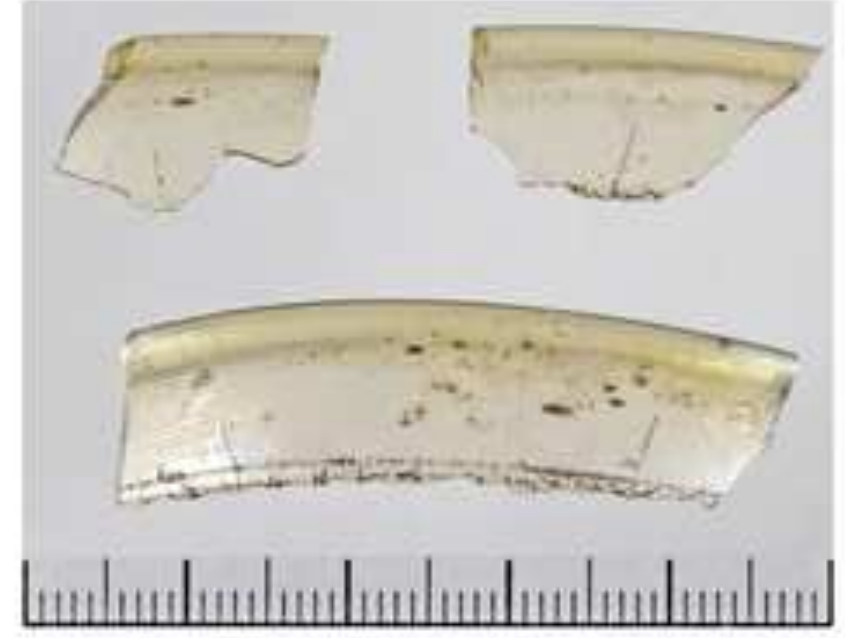

23

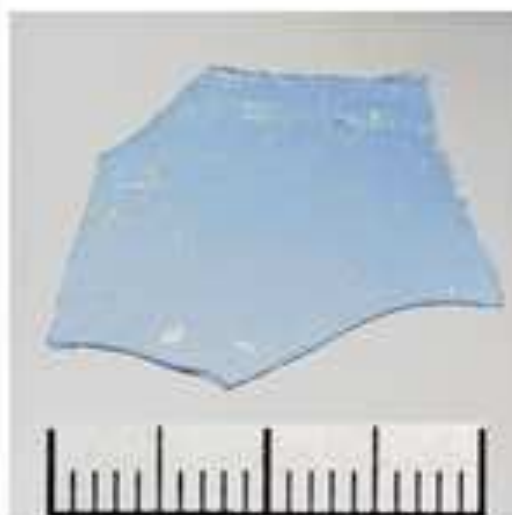

49

Blue

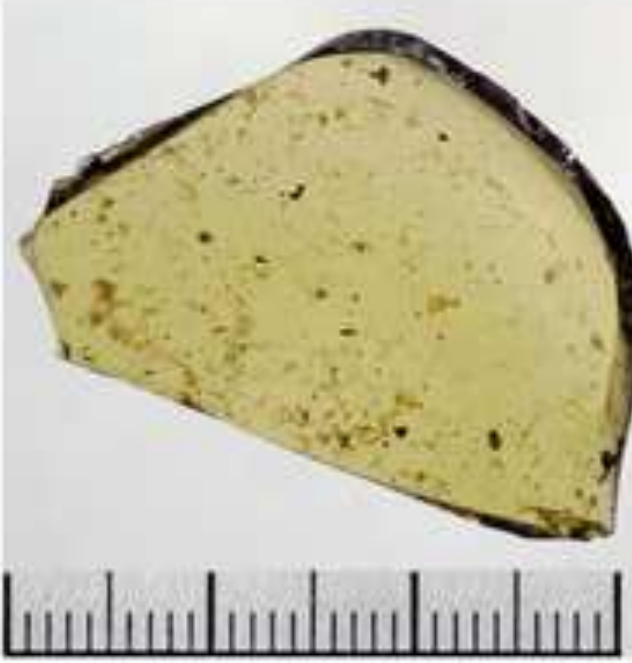

42

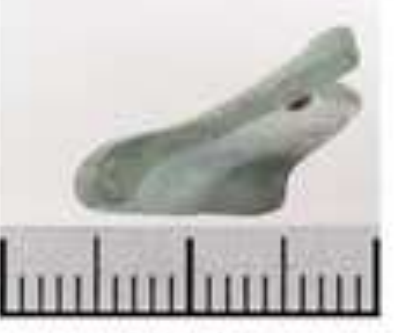

37 Light blue 
Figure 3

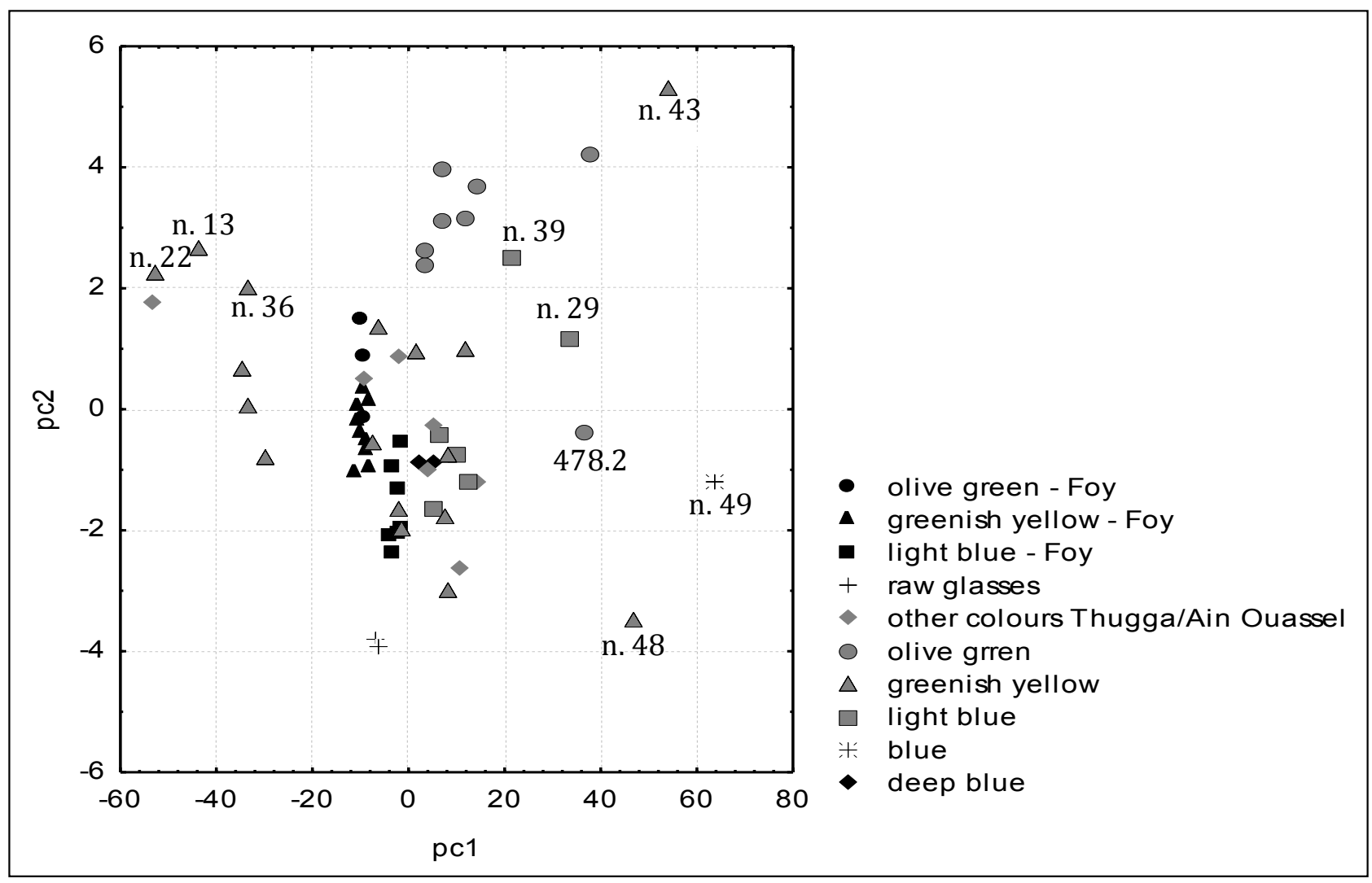



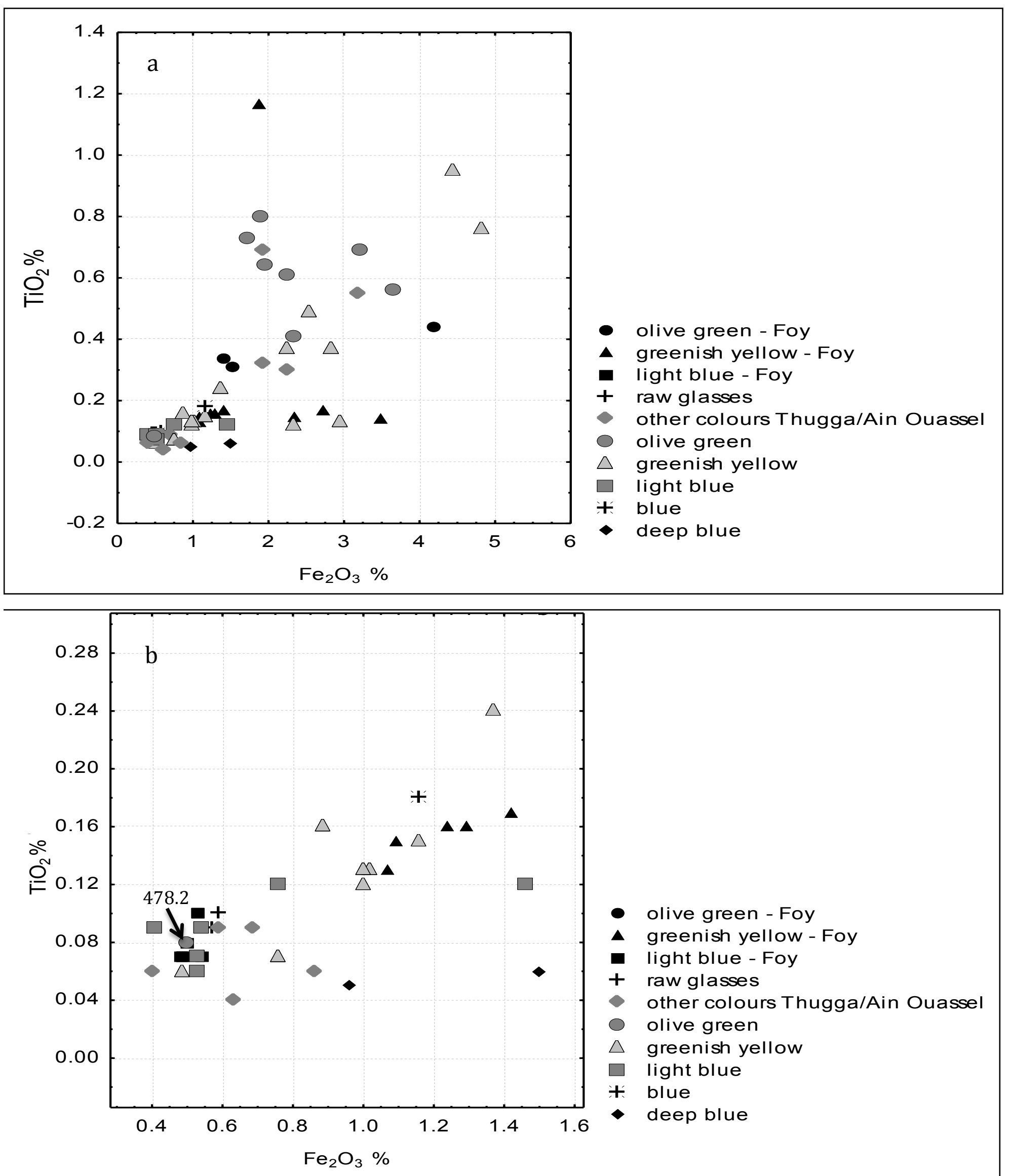
Figure 5

Figure 5

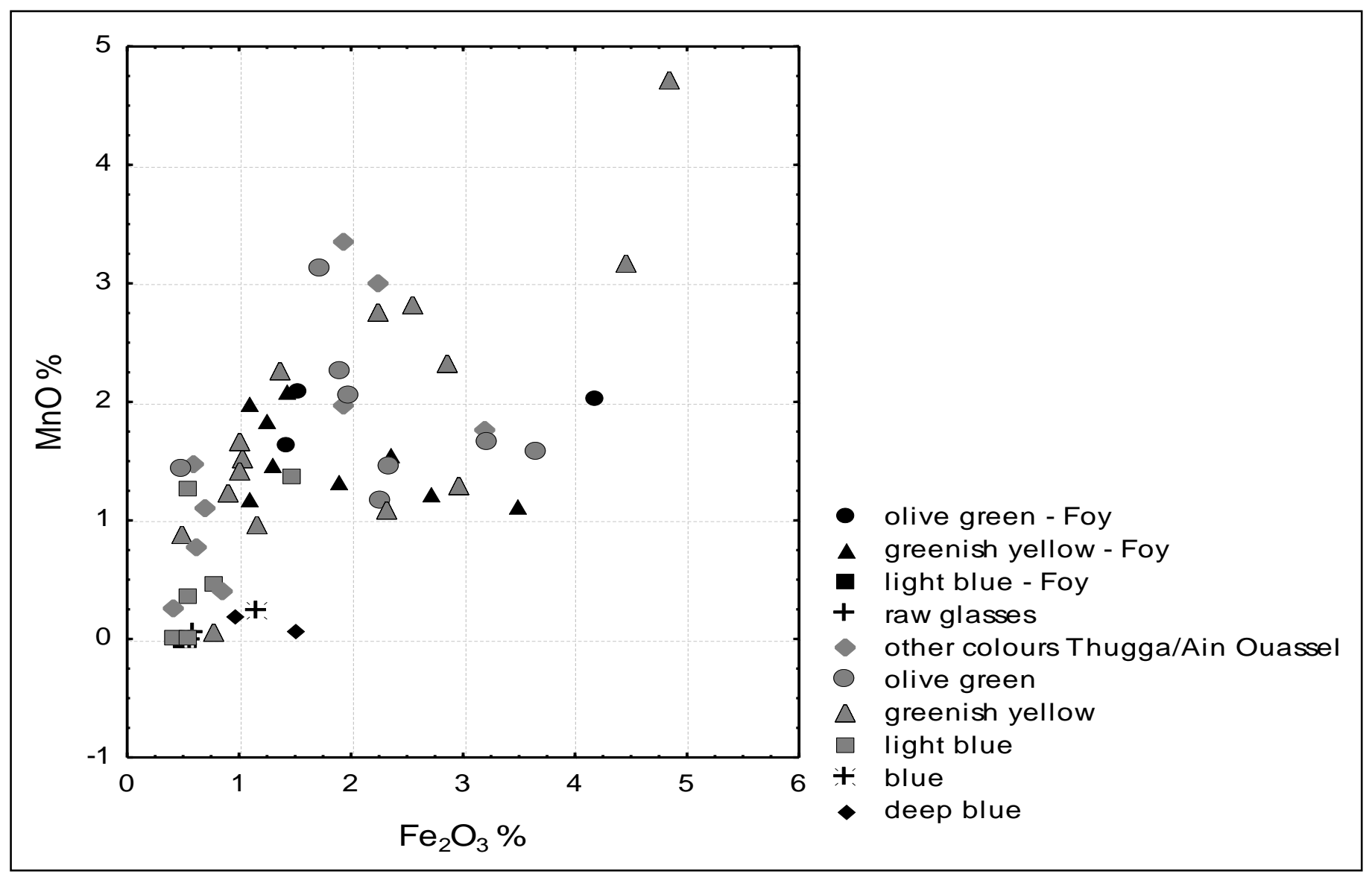


Figure 6

Figure 6

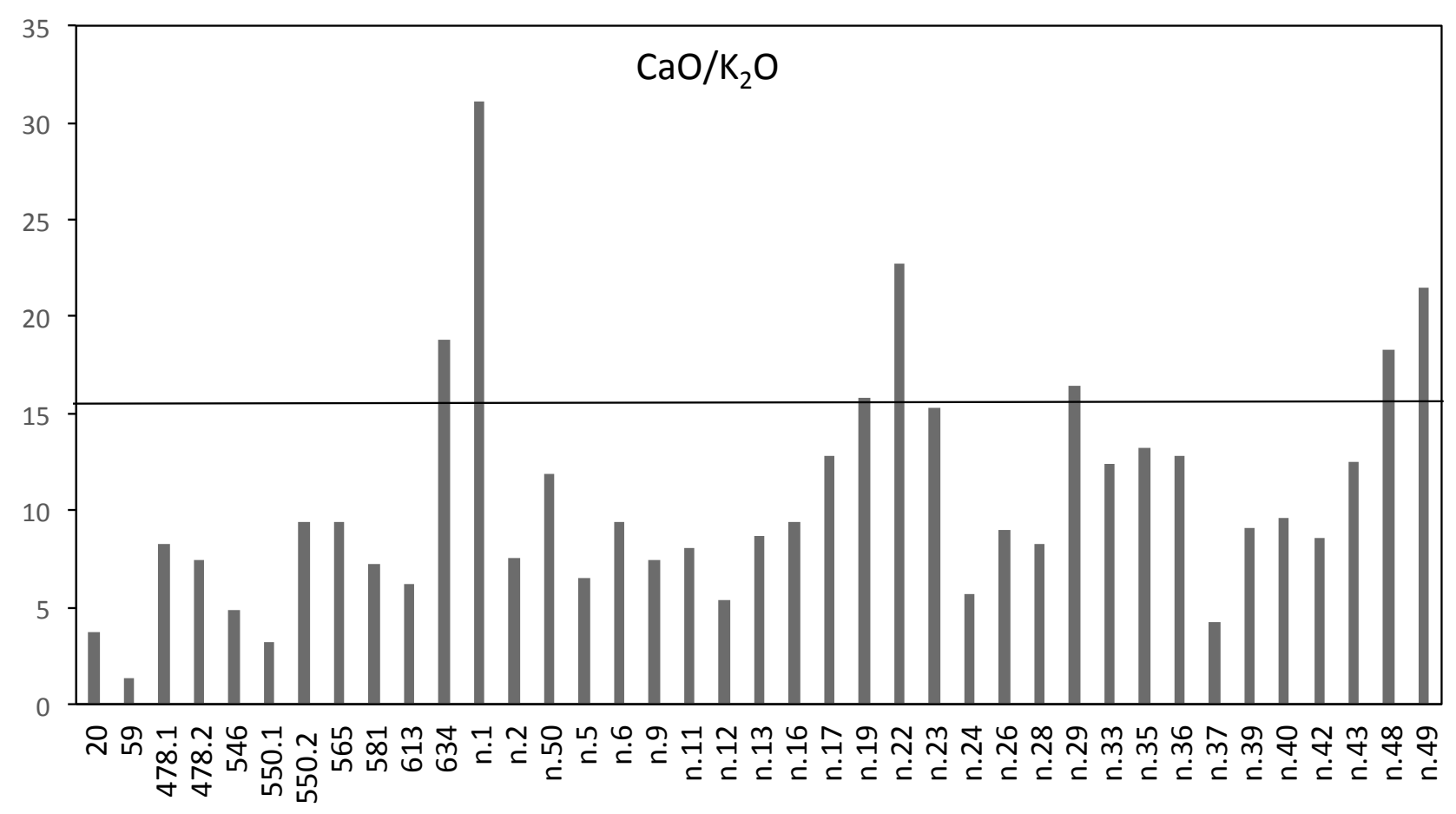


Figure 7

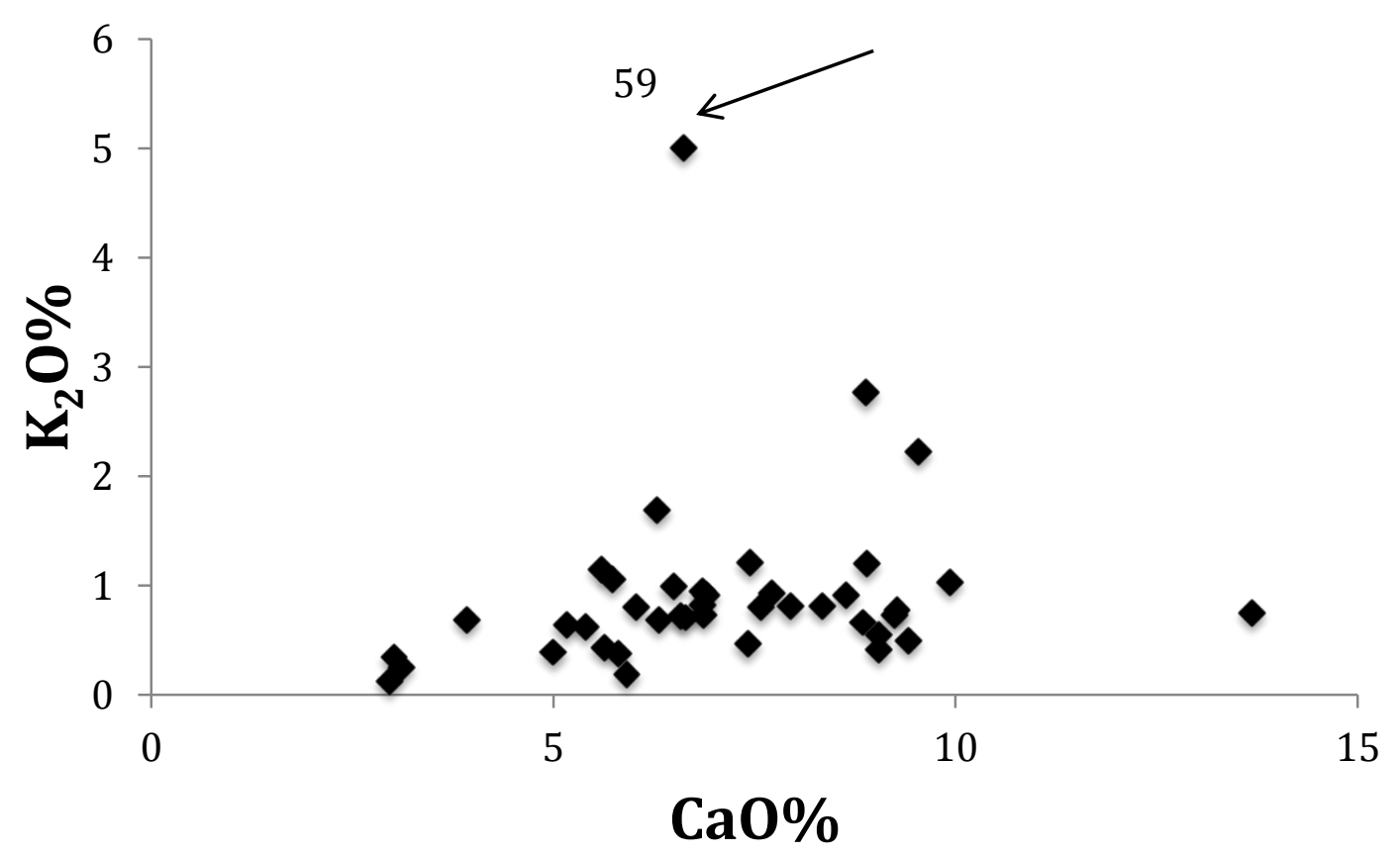

Figure 7 
Figure 8

Figure 8

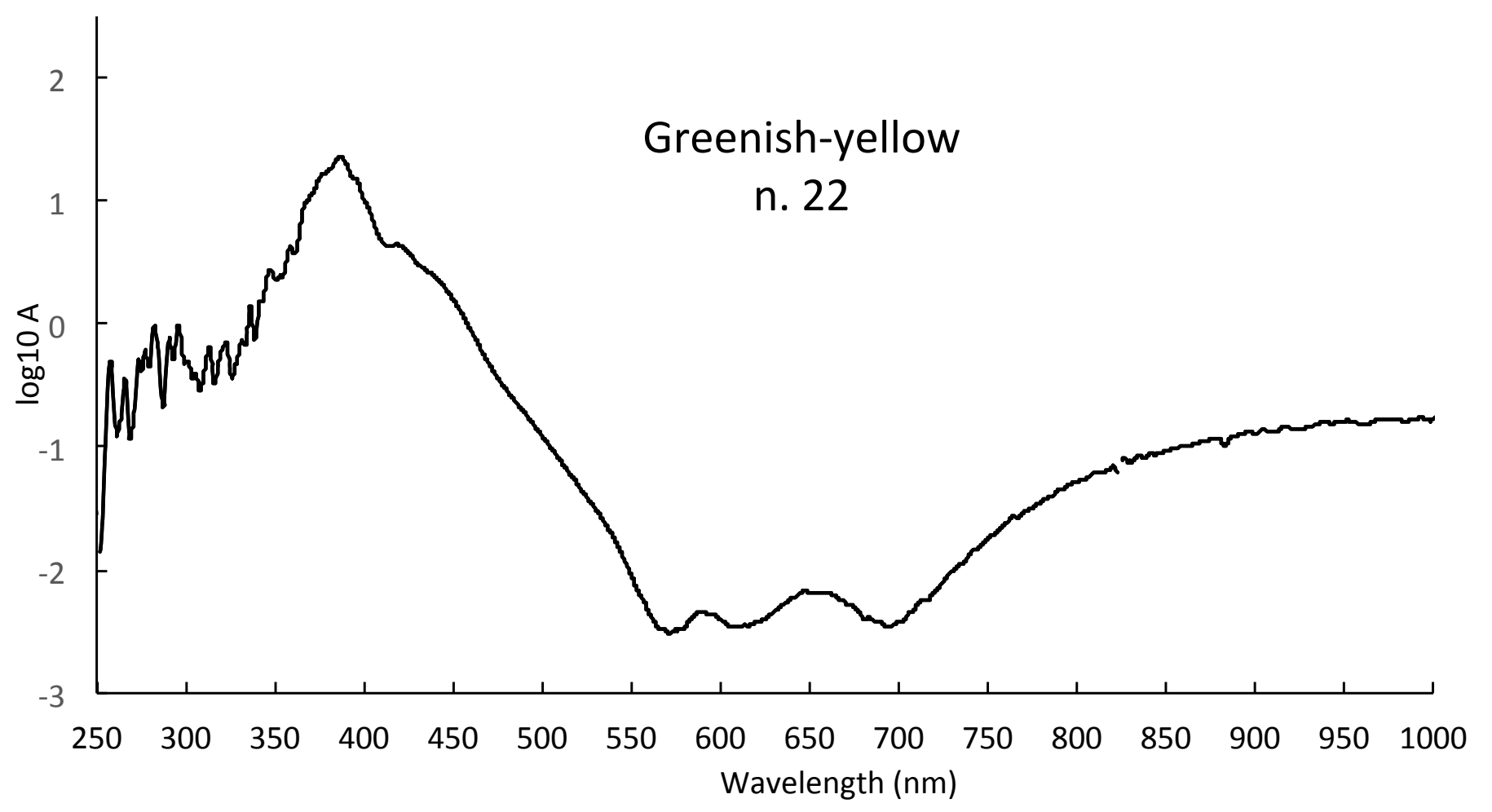


Figure 9

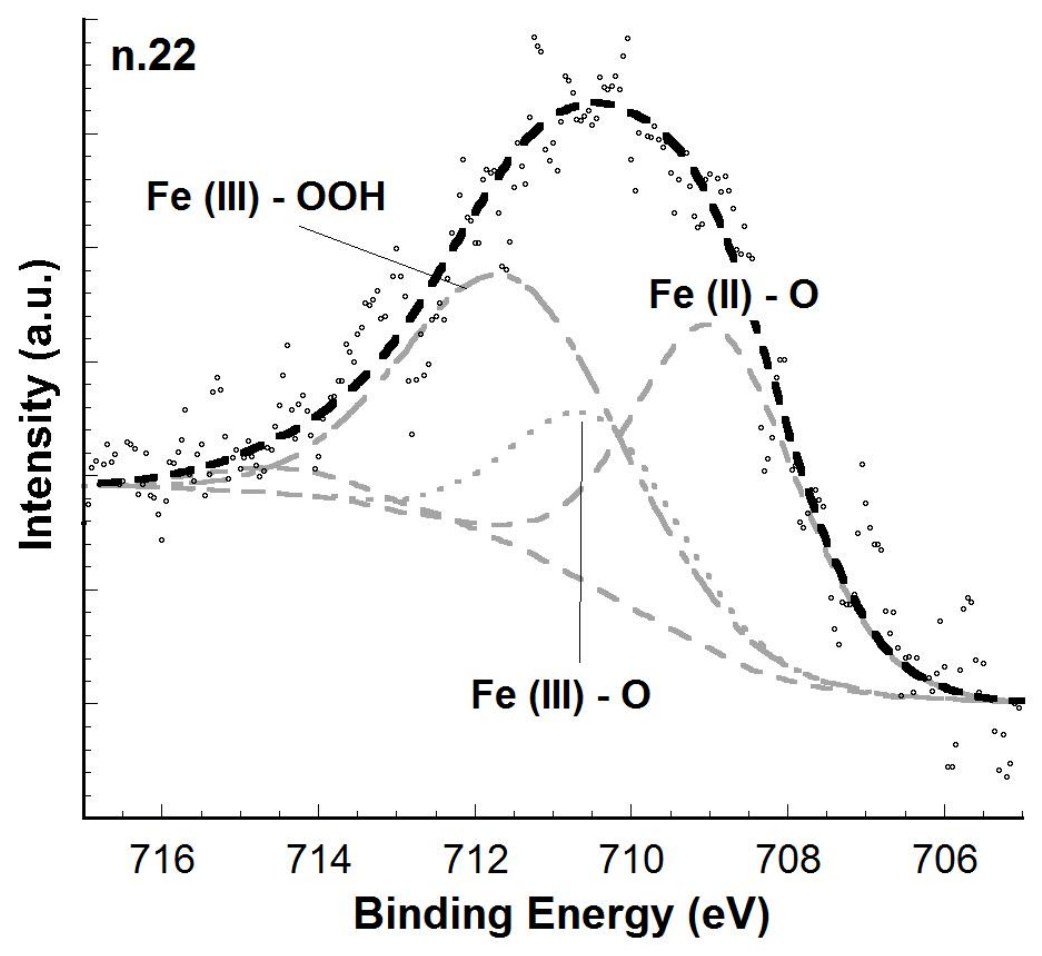


Click here to download high resolution image

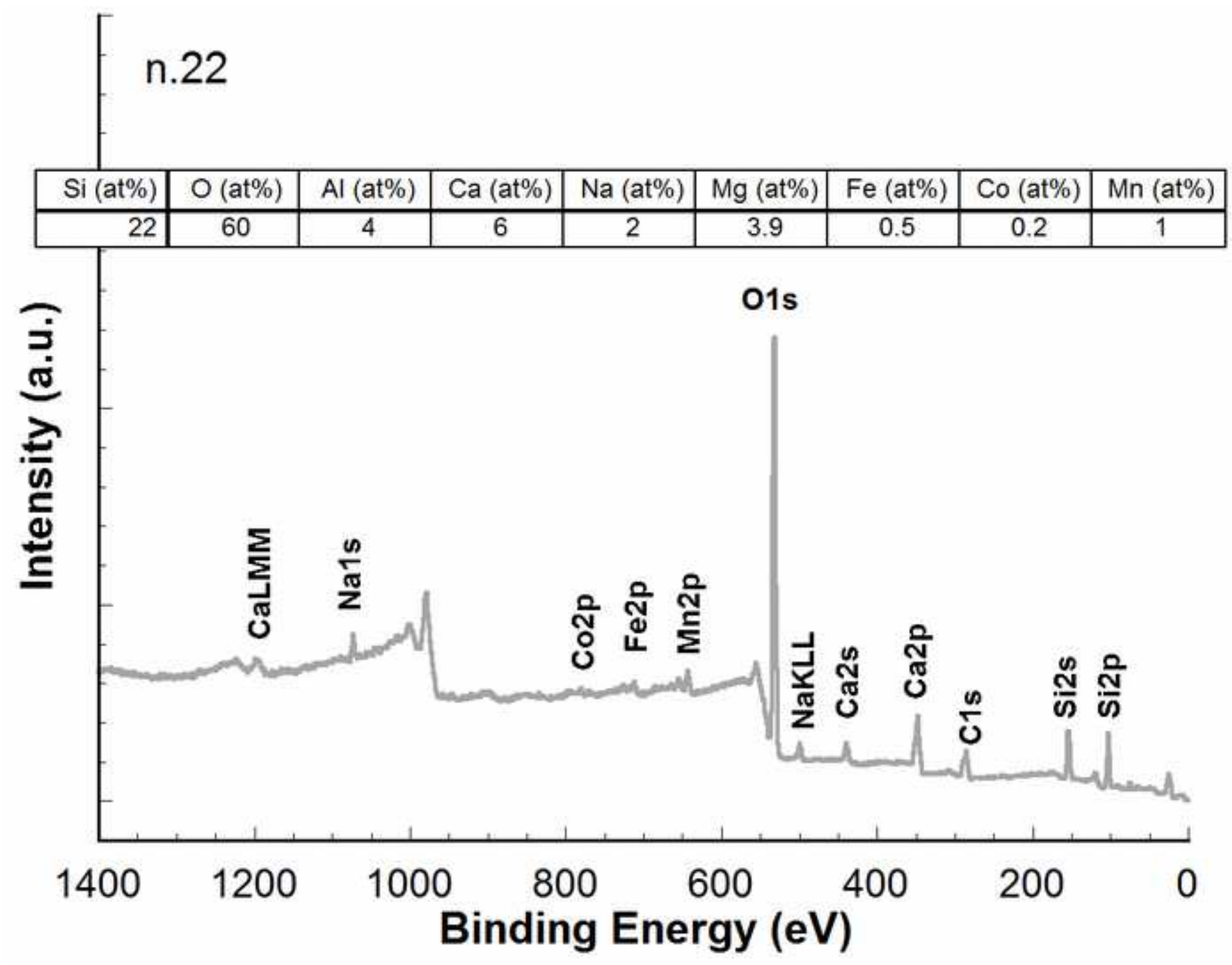


Figure 11

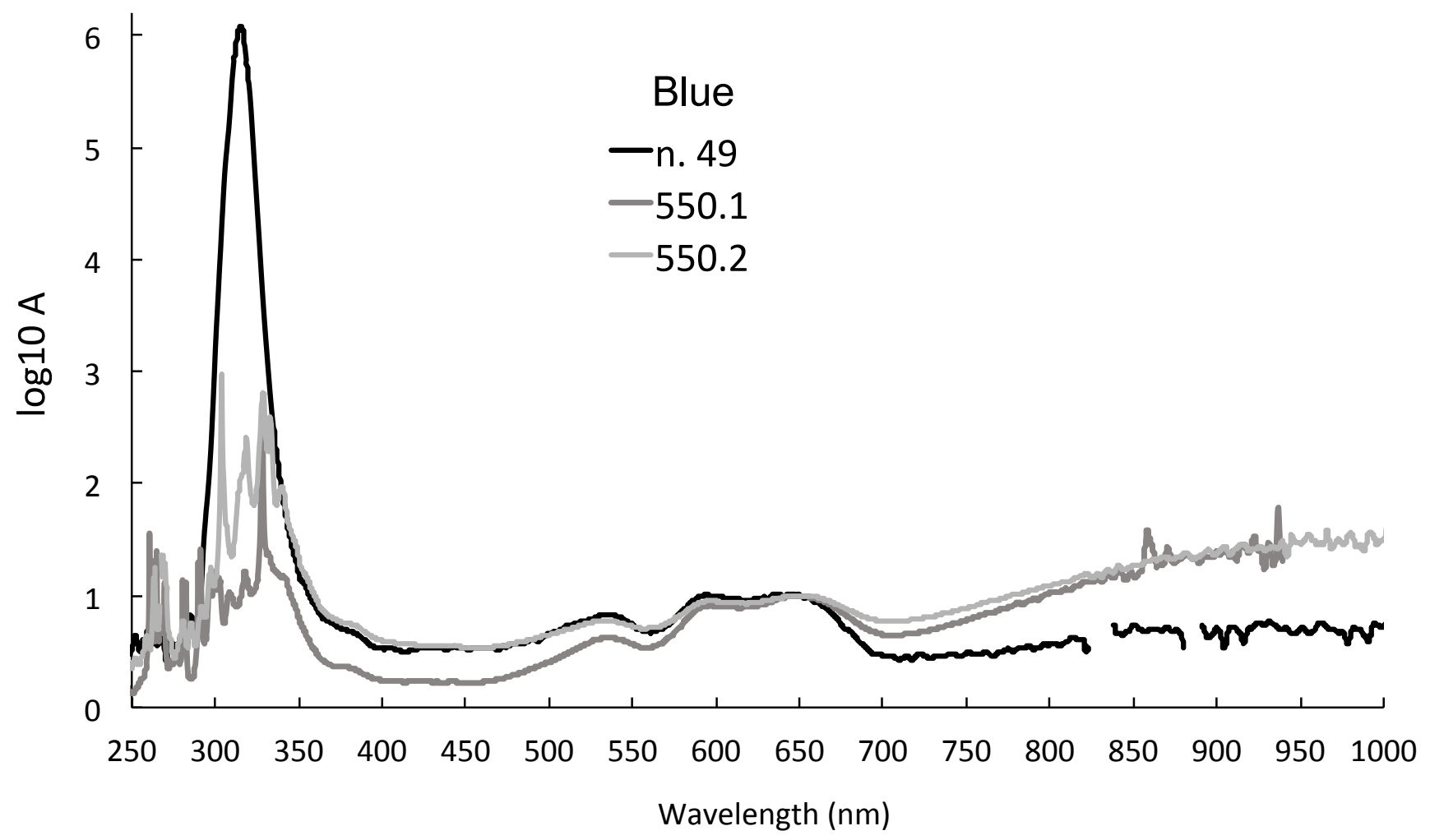


Figure 12

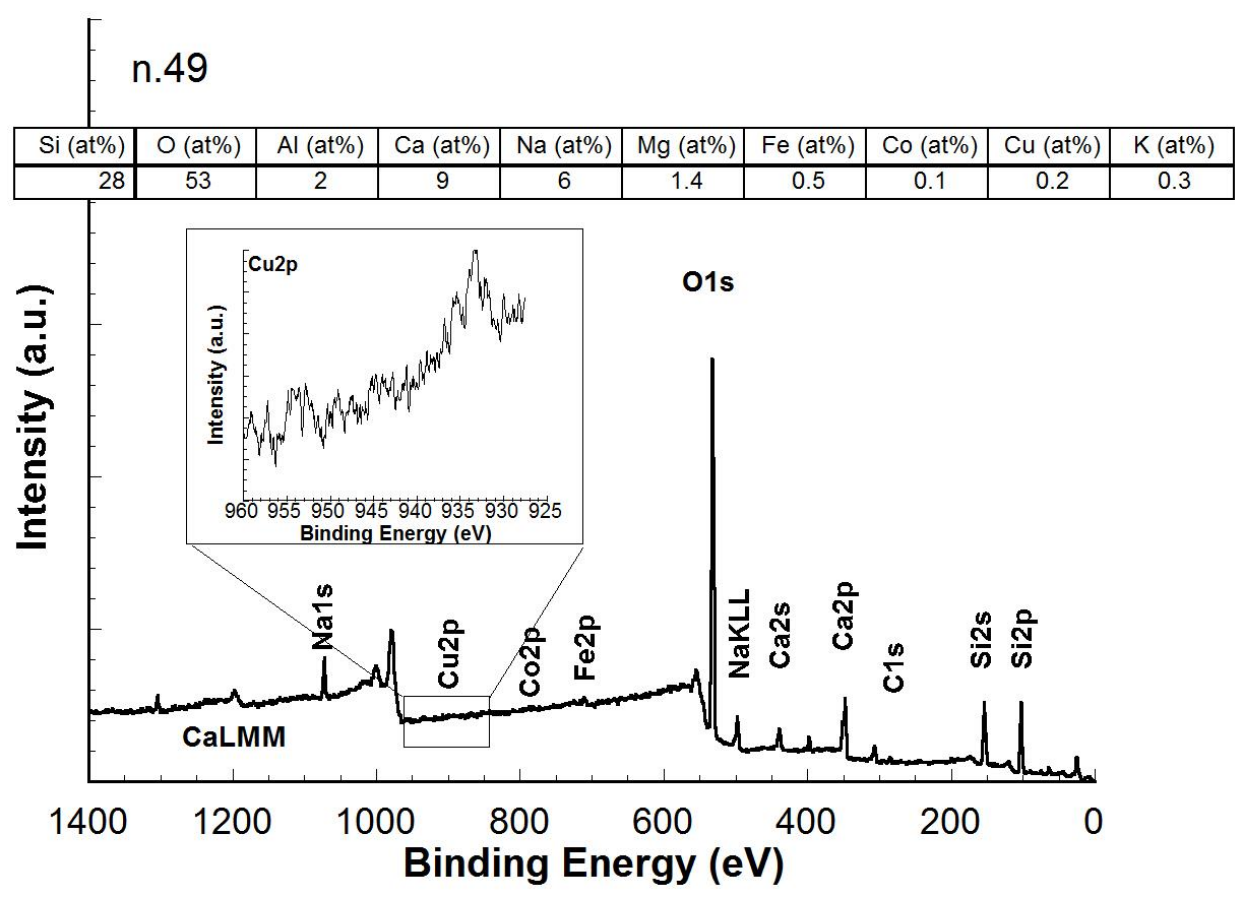


Figure 13

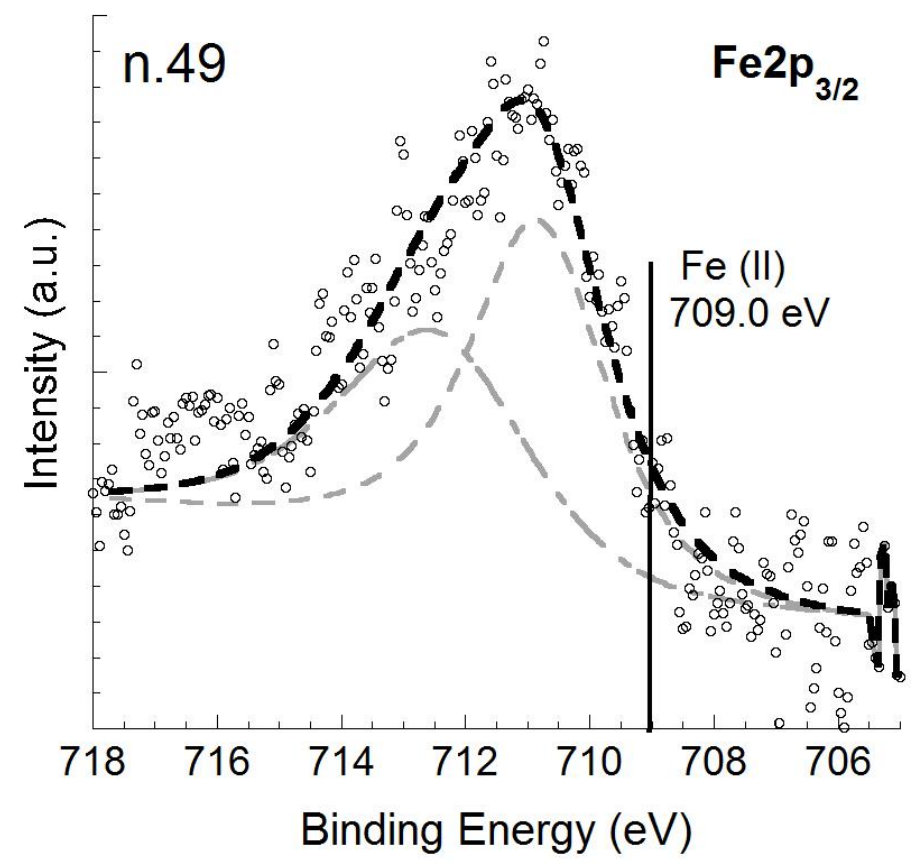


Figure 14

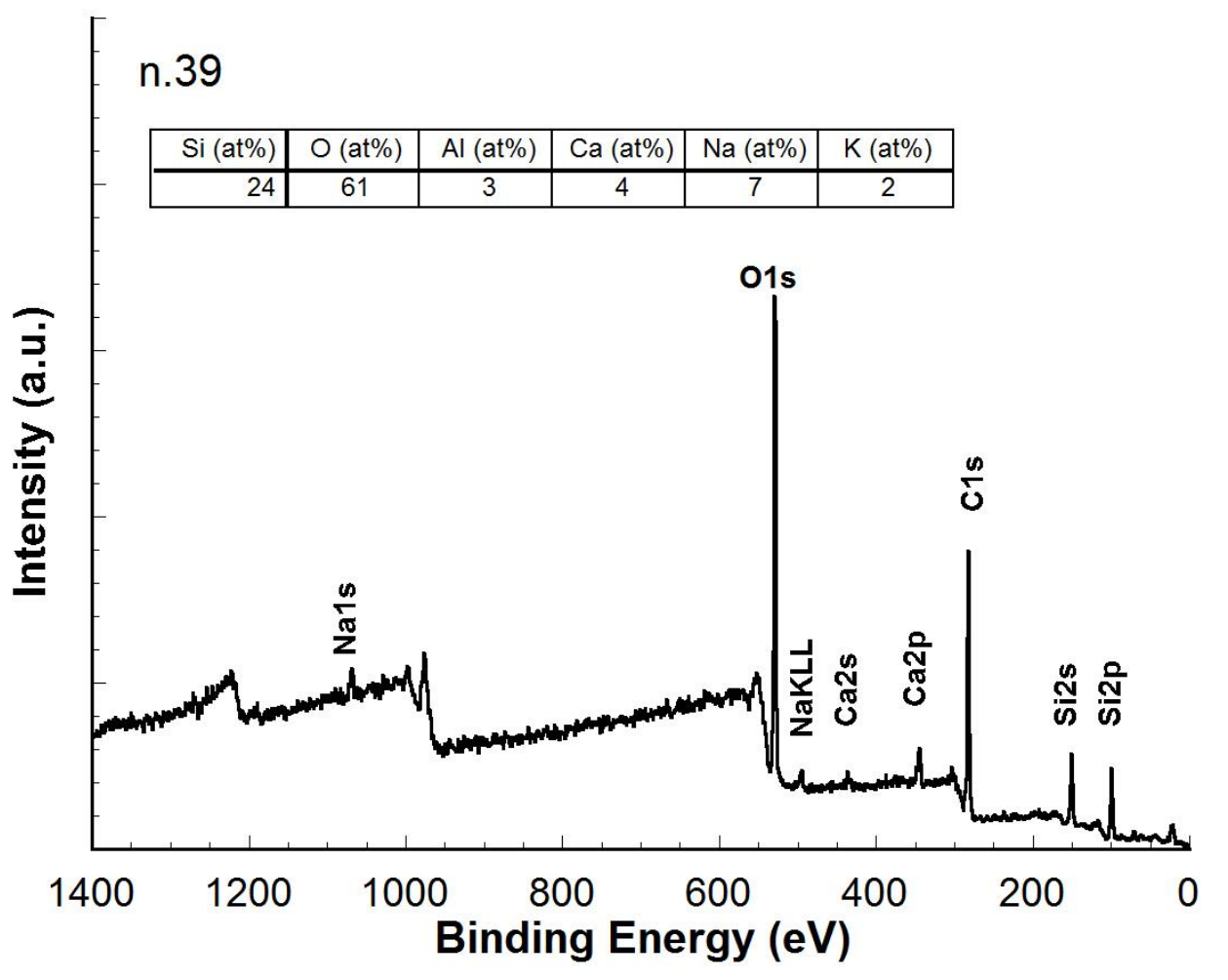


Figure 15

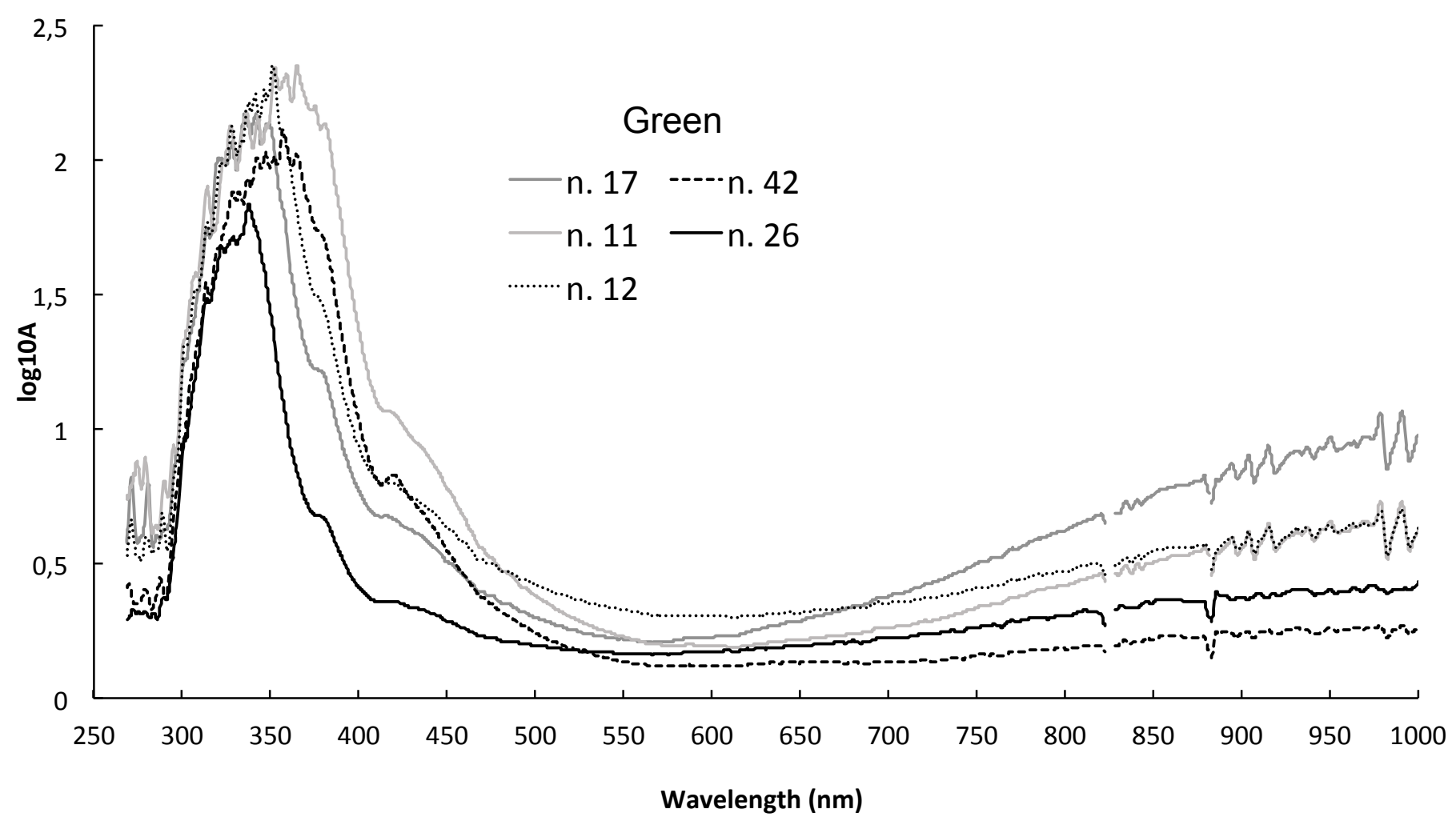




\section{Captions to figures}

\section{Figure 1}

Roman-Byzantine farm excavation at Aïn Ouassel. Northern Tunisia.

\section{Figure 2}

Some examples selected among the analyzed Roman-Byzantine glass shards from Aïn Ouassel.

\section{Figure 3}

Principal component analysis (PCA) carried out on XRF chemical compositional data for the analysed glass shards; three reference groups and two raw glasses from Carthage reported in the literature [19. 20. 22. 23] have been included for comparison.

\section{Figure 4}

$\mathrm{TiO}_{2} \%$ vs $\mathrm{Fe}_{2} \mathrm{O}_{3} \%$ for both analysed glass shards and reference groups (a); an enlargement of the area in the lower left side is shown in (b).

\section{Figure 5}

$\mathrm{MnO} \%$ vs $\mathrm{Fe}_{2} \mathrm{O}_{3} \%$ for both analysed glass shards and reference groups.

\section{Figure 6}

$\mathrm{CaO} / \mathrm{K}_{2} \mathrm{O}$ ratio for all the analysed glass shards.

\section{Figure 7}

$\mathrm{CaO} \%$ vs $\mathrm{K}_{2} \mathrm{O} \%$ for all the analysed glass shards evidencing the only sample (n. 59) for which plant ash has been identified as flux.

\section{Figure 8}

FORS spectrum acquired on a yellow glass shard, n.22.

\section{Figure 9}

High-resolution $\mathrm{X}$ - ray photoelectron spectrum of $\mathrm{Fe} 2 \mathrm{p}_{3 / 2}$ signal on the yellow n.22 sample.

\section{Figure 10}

Survey $\mathrm{X}$ - ray photoelectron spectrum of the yellow n.22 sample. Surface quantitative composition (at\%) is reported on the table. Accuracy is estimated to be $\pm 10 \%$.

\section{Figure 11}

FORS spectra acquired on some blue glass shards. 


\section{Figure 12}

Survey $\mathrm{X}$ - ray photoelectron spectrum of the blue n. 49 sample. Surface quantitative composition (at\%) is reported on the table. Accuracy is estimated to be $\pm 10 \%$. High-resolution $\mathrm{Cu} 2 \mathrm{p}$ peak is shown in the inset.

\section{Figure 13}

High-resolution $\mathrm{X}$ - ray photoelectron spectrum of $\mathrm{Fe} 2 \mathrm{p}_{3 / 2}$ signal in the blue $\mathrm{n} .49$ sample.

\section{Figure 14}

Survey X - ray photoelectron spectrum of the colourless n. 39 sample. Surface quantitative composition (at\%) is reported on the table. Accuracy is estimated to be $\pm 10 \%$.

\section{Figure 15}

FORS spectra acquired on some green glass shards. 


\section{Table 1}

Description. colour and dating period of the examined glasses coming from the survey and from the excavation; a question mark is reported in the case the shape of the object or the dating period are uncertain.

\begin{tabular}{|c|c|c|c|}
\hline $\begin{array}{c}\text { Sample notation } \\
\text { survey }\end{array}$ & Description & Colour & Dating period \\
\hline 20 & bracelet & deep green & Roman \\
\hline 59 & unidentified & turquoise & \\
\hline 478.1 & cup & light yellow & $1^{\text {st }}-2^{\text {nd }}$ cent. \\
\hline 478.2 & dish & olive green & $2^{\text {nd }}-4^{\text {th }}$ cent. \\
\hline 546 & bracelet & deep green & $7^{\text {th }}$ cent.? \\
\hline 550.1 & handle & deep blue & $6^{\text {th }}$ cent. \\
\hline 550.2 & goblet & deep blue & $6^{\text {th }}$ cent. \\
\hline 565 & window? & light blue & \\
\hline 581 & beaker & colourless & $6^{\text {th }}$ cent. \\
\hline 613 & goblet & yellowish & $6^{\text {th }}$ cent. \\
\hline 634 & goblet & turquoise & $7^{\text {th }}$ cent. \\
\hline \multicolumn{4}{|l|}{$\begin{array}{c}\text { Sample notation } \\
\text { excavation }\end{array}$} \\
\hline n. 1 & dish & light green & $5^{\text {th }}-6^{\text {th }}$ cent. \\
\hline n. 2 & dish & greenish-colourless & $5^{\text {th }}-6^{\text {th }}$ cent. \\
\hline n. 5 & bowl & colourless & $5^{\text {th }}-6^{\text {th }}$ cent. \\
\hline n. 6 & bowl & greenish-yellow & $5^{\text {th }}-6^{\text {th }}$ cent. \\
\hline n. 9 & beaker & olive green & $5^{\text {th }}$ cent. \\
\hline n. 11 & beaker & olive green & $5^{\text {th }}$ cent. \\
\hline n. 12 & beaker? & olive green & 5 th cent. \\
\hline n. 13 & beaker & greenish-yellow & $6^{\text {th }}$ cent. \\
\hline n. 16 & beaker & olive green & $5^{\text {th }}$ cent. \\
\hline n. 17 & beaker & olive green & $5^{\text {th }}$ cent. \\
\hline n. 19 & beaker? & light green & $5^{\text {th }}$ cent. \\
\hline n. 22 & goblet & yellowish & $6^{\text {th }}$ cent. \\
\hline n. 23 & goblet & greenish-yellow & $6^{\text {th }}$ cent. \\
\hline n. 24 & goblet & light yellow & $6^{\text {th }}$ cent. \\
\hline n. 26 & goblet & olive green & $6^{\text {th }}$ cent. \\
\hline n. 28 & goblet & greenish-yellow & $6^{\text {th }}$ cent. \\
\hline n. 29 & goblet & turquoise & $7^{\text {th }}$ cent. \\
\hline n. 33 & goblet & purple & $6^{\text {th }}$ cent. \\
\hline n. 35 & goblet & greenish & $6^{\text {th }}$ cent. \\
\hline n. 36 & goblet & yellowish & $6^{\text {th }}$ cent. \\
\hline n. 37 & goblet & turquoise & $7^{\text {th }}$ cent. \\
\hline n. 39 & lamp? & colourless & $7^{\text {th }}$ cent. \\
\hline n. 40 & lamp? & yellowish & $6^{\text {th }}$ cent. \\
\hline n. 42 & beaker? & olive green & $5^{\text {th }}$ cent. \\
\hline n. 43 & flask & greenish & $5^{\text {th }}-6^{\text {th }}$ cent. \\
\hline n. 48 & unidentified & greenish & \\
\hline n. 49 & unidentified & blue & \\
\hline n. 50 & bowl & yellowish & $5^{\text {th }}-6^{\text {th }}$ cent. \\
\hline
\end{tabular}


Table 2 Chemical composition (oxides weight percentages) determined by XRF.

\begin{tabular}{|c|c|c|c|c|c|c|c|c|}
\hline $\begin{array}{c}\text { Sample } \\
\text { notation }\end{array}$ & $\mathrm{CaO}$ & $\mathrm{Fe}_{2} \mathrm{O}_{3}$ & $\mathrm{Ti}_{2} \mathrm{O}$ & $\mathrm{K}_{2} \mathrm{O}$ & $\mathrm{SiO}_{2}$ & $\mathbf{A l}_{2} \mathbf{O}_{3}$ & MnO & $\mathbf{P}_{2} \mathbf{O}_{5}$ \\
\hline 20 & 6.29 & 1.92 & 0.69 & 1.69 & 71.66 & 2.82 & 1.98 & 0.61 \\
\hline 59 & 6.61 & 0.76 & 0.12 & 5.01 & 83.71 & 4.43 & 0.47 & 0.17 \\
\hline 478.1 & 6.86 & 2.25 & 0.37 & 0.83 & 67.69 & 1.77 & 2.75 & 0.08 \\
\hline 478.2 & 8.90 & 0.50 & 0.08 & 1.20 & 90.00 & 4.67 & 1.43 & 0.06 \\
\hline 546 & 5.60 & 3.20 & 0.55 & 1.15 & 64.63 & 4.06 & 1.76 & 0.45 \\
\hline 550.1 & 8.88 & 1.50 & 0.06 & 2.77 & 79.23 & 2.37 & 0.08 & 0.66 \\
\hline 550.2 & 6.87 & 0.96 & 0.05 & 0.73 & 76.22 & 3.97 & 0.19 & 0.27 \\
\hline 565 & 7.58 & 0.53 & 0.06 & 0.81 & 80.11 & 2.75 & $\begin{array}{l}0.37 \\
\end{array}$ & 0.23 \\
\hline 581 & 6.86 & 0.69 & 0.09 & 0.95 & 88.07 & 5.91 & 1.1 & 0.19 \\
\hline 613 & 7.44 & 2.97 & 0.13 & 1.21 & 75.43 & 2.08 & 1.29 & 0.37 \\
\hline 634 & 9.41 & 0.41 & 0.09 & 0.5 & 78.94 & 2.58 & 0.02 & 0.25 \\
\hline n.1 & 5.91 & 0.89 & 0.16 & 0.19 & 81.68 & 9.33 & 1.23 & 0.82 \\
\hline n. 2 & 6.89 & 1.16 & 0.15 & 0.92 & 66.41 & 3.07 & 0.97 & 0.06 \\
\hline n.3 & 9.27 & 1.37 & 0.24 & 0.78 & 71.93 & 3.86 & 2.26 & 0.06 \\
\hline n.5 & 6.49 & 0.59 & 0.09 & 0.99 & 84.61 & 8.37 & 1.48 & 0.11 \\
\hline n.6 & 8.64 & 1.00 & 0.13 & 0.92 & 72.29 & 4.34 & 1.41 & 0.06 \\
\hline n.9 & 6.03 & 1.97 & 0.64 & 0.81 & 88.01 & 0.19 & 2.06 & 0.06 \\
\hline n.11 & 5.16 & 3.65 & 0.56 & 0.64 & 81.07 & 2.04 & 1.58 & 0.22 \\
\hline n.12 & 5.73 & 3.21 & 0.69 & 1.06 & 77.19 & 1.68 & 1.67 & 0.15 \\
\hline n.13 & 3.02 & 2.56 & 0.49 & 0.35 & 30.37 & 0.19 & 2.81 & 0.04 \\
\hline n.16 & 6.64 & 1.91 & 0.8 & 0.71 & 90.00 & 1.04 & 2.25 & 0.08 \\
\hline n.17 & 5.63 & 2.27 & 0.61 & 0.44 & 77.19 & 1.4 & 1.16 & 0.06 \\
\hline n.19 & 7.41 & 0.86 & 0.06 & 0.47 & 44.26 & 0.45 & 0.41 & 0.06 \\
\hline n.22 & 2.96 & 4.83 & 0.76 & 0.13 & 21.39 & 2.48 & 4.72 & 0.07 \\
\hline n. 23 & 5.8 & 2.85 & 0.37 & 0.38 & 39.56 & 1.46 & 2.32 & 0.11 \\
\hline n. 24 & 3.92 & 0.49 & 0.06 & 0.69 & 40.4 & 2.13 & 0.88 & 0.06 \\
\hline n.26 & 6.58 & 2.34 & 0.41 & 0.73 & 85.8 & 0.19 & 1.45 & 0.06 \\
\hline n. 28 & 7.71 & 2.33 & 0.12 & 0.93 & 81.8 & 4.74 & 1.08 & 0.27 \\
\hline n.29 & 9.04 & 0.53 & 0.07 & 0.55 & 90.00 & 1.1 & 0.02 & 0.06 \\
\hline n. 33 & 3.11 & 2.25 & 0.3 & 0.25 & 20.83 & 0.59 & 3 & 0.06 \\
\hline n.35 & 8.85 & 1.02 & 0.13 & 0.67 & 85.96 & 0.66 & 1.51 & 0.06 \\
\hline n.36 & 4.99 & 1.93 & 0.32 & 0.39 & 40.32 & 0.19 & 3.36 & 0.06 \\
\hline n.37 & 9.53 & 1.46 & 0.12 & 2.23 & 85.94 & 3.61 & 1.38 & 0.15 \\
\hline n.39 & 6.3 & 0.54 & 0.09 & 0.69 & 95.7 & 1.19 & 1.26 & 0.06 \\
\hline n. 40 & 9.93 & 1 & 0.12 & 1.03 & 81.26 & 3.73 & 1.67 & 0.15 \\
\hline n. 42 & 5.4 & 1.72 & 0.73 & 0.63 & 81.27 & 0.19 & 3.12 & 0.06 \\
\hline n. 43 & 9.23 & 4.45 & 0.95 & 0.74 & 90.00 & 0.19 & 3.17 & 0.06 \\
\hline n. 48 & 13.69 & 0.76 & 0.07 & 0.75 & 90.00 & 5.4 & 0.05 & 0.06 \\
\hline n. 49 & 9.04 & 1.16 & 0.18 & 0.42 & 90.00 & 8.18 & 0.23 & 0.06 \\
\hline
\end{tabular}


Table 3

$\mathrm{Ni} / \mathrm{Co}$ ratio (weight percentage) for nickel bearing glasses.

\begin{tabular}{|c|c|c|c|c|c|}
\hline sample & n. 2 & n. 22 & n. 49 & 550.1 & 550.2 \\
\hline $\mathbf{N i} / \mathbf{C o}$ & 0.36 & 2.1 & 0.33 & 0.07 & 0.06 \\
\hline
\end{tabular}


supporting information
Click here to download Supplementary Interactive Plot Data (CSV): Supporting Information.docx (n)

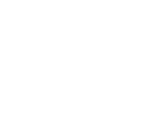
$\sqrt{2}$ (1) (l) $\sqrt{20}$ (1) $\sqrt{20}$

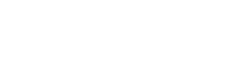
(1) (1)

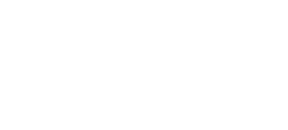

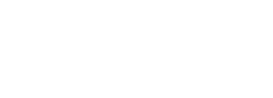
. . . . . . . . . . . . . . . . .

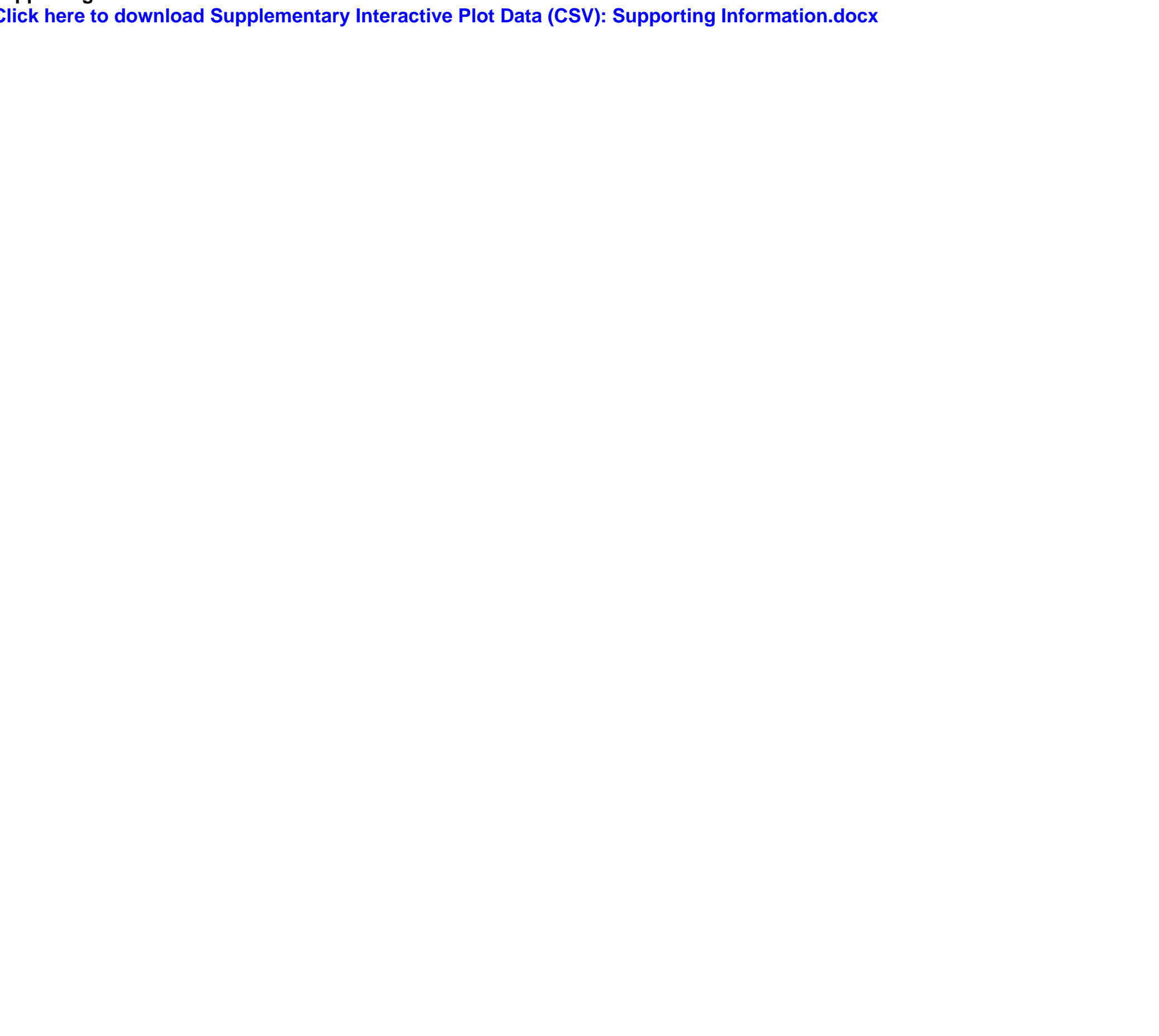

